\title{
Gold Nanoclusters as Nano-Antibiotic Auranofin Analogues
}

\author{
William Ndugire, ${ }^{1}$ N.G. Hasitha Raviranga, ${ }^{1}$ Jingzhe Lao, ${ }^{1}$ Olof Ramström, ${ }^{* 1,2}$ Mingdi Yan*1 \\ ${ }^{1}$ Department of Chemistry, University of Massachusetts Lowell, One University Ave., Lowell, MA 01854, USA; ${ }^{2}$ Department \\ of Chemistry and Biomedical Sciences, Linnaeus University, SE-39182 Kalmar, Sweden
}

\begin{abstract}
Auranofin, a gold(I)-complex with tetraacetylated thioglucose and triethylphosphine ligands, is an FDA-approved drug as an anti-inflammatory aid in the treatment of rheumatoid arthritis. In repurposing auranofin for other diseases, it was found that the drug showed significant activity against Gram-positive bacteria but was inactive against Gram-negative bacteria. Herein, we report the design and synthesis of gold nanoclusters (AuNCs) based on the structural motif of auranofin. Phosphine-capped AuNCs were synthesized and glycosylated, yielding auranofin AuNC analogues with mixed phosphine/thioglucose ligand shells. These AuNCs were active against both Gram-negative and Gram-positive bacteria, including a panel of resistant ESKAPE pathogens. Notably, an auranofin analogue, a mixed-ligand $1.6 \mathrm{~nm}$ AuNC (4b) was $\sim 4$ times more active than auranofin against Pseudomonas aeruginosa, while exhibiting 24 times lower toxicity against human A549 cells. The enhanced antibacterial activity of these AuNCs was characterized by a greater uptake of $\mathrm{Au}$ by the bacteria compared to $\mathrm{Au}^{\mathrm{I}}$-complexes ( $20 \%$ for AuNC $\mathbf{4 b}$ ). Additional factors include increased oxidative stress, moderate inhibition of thioredoxin reductase (TrxR), and DNA damage. Most intriguingly, the AuNCs were not affected by the bacterial outer membrane $(\mathrm{OM})$ barrier or by extracellular proteins. This contrasts with $\mathrm{Au}^{\mathrm{I}-}$ complexes like auranofin that are susceptible to protein binding and hindered by the OM barrier.
\end{abstract}

\section{INTRODUCTION}

The staggering rate of antimicrobial resistance is one of the foremost crises facing global public health. A recent report by the Centers for Disease Control and Prevention (CDC) estimated that up to 3 million people suffered from infections caused by antibiotic-resistant bacteria in $2019 .{ }^{1}$ Besides the rise in community-acquired infections, the rapid increase in nosocomial infections threatens the safety of in-patient medical procedures. In 2017, up to 32,600 cases of multidrug-resistant (MDR) Pseudomonas aeruginosa infection occurred in hospitals in the US, resulting in 2,700 deaths. ${ }^{1}$ As a result, new therapies are needed, especially approaches that can offer alternative mechanisms to combat the antimicrobial resistance observed against traditional antibiotics. A convenient strategy that is becoming more widespread is the redirection of non-antibiotic drugs into the antimicrobial pipeline - socalled drug repurposing. Repurposing drugs is associated with reduced regulatory costs and time to market. ${ }^{2,3}$

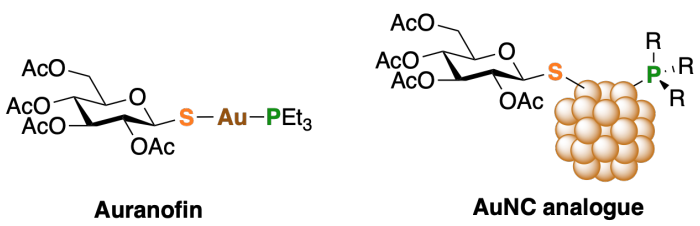

Figure 1: Structures of auranofin and AuNC analogue 
Auranofin is an FDA-approved drug previously used as an anti-inflammatory drug in the treatment of rheumatoid arthritis (Figure 1). It has since been tested for other diseases, showing antibacterial, ${ }^{4-11}$ antifungal, ${ }^{12-14}$ antiparasitic, ${ }^{15,16}$ antiviral, ${ }^{17-21}$ and antitumor ${ }^{22}$ activities. The main mode of action (MOA) of auranofin has been suggested to be inhibition of thioredoxin reductase (TrxR). ${ }^{23,24}$ The thioredoxin (Trx) system is critical in maintaining the redox homeostasis by controlling the intracellular disulfide/thiol concentration in both bacteria and mammalian cells. ${ }^{25,26}$ Auranofin has shown high activity against Gram-positive bacteria but is inactive against Gram-negative strains. ${ }^{9,10,27}$ The lack of Gram-negative activity has been attributed to the outer membrane $(\mathrm{OM})$ barrier, leading to reduced drug uptake. ${ }^{27}$ It has also been suggested that the glutathione/glutaredoxin (GSH/Grx) system present in Gramnegative bacteria counteract the inhibition of the Trx/TrxR system, thereby reducing the oxidative stress level. ${ }^{28}$

Gold nanoclusters (AuNCs) are a class of gold nanoparticles that contain up to several hundred $\mathrm{Au}$ atoms and are $2 \mathrm{~nm}$ or less in diameter. ${ }^{29,30}$ Similar to other nanomaterials, AuNCs can provide multivalent presentation of attached ligands within close proximity. The multivalent effect often leads to a marked increase in binding affinity by several orders of magnitude. ${ }^{31}$ This property has been exploited, for example, by conjugating antibiotics such as vancomycin, daptomycin, bacitracin, surfactin, and beta-lactams to AuNCs to enhance their activities. ${ }^{32-37}$ Another common approach is to conjugate charged species, particularly cationic ligands, to AuNCs. ${ }^{38-41}$ The resulting positively-charged AuNCs disrupt the negatively-charged bacterial membrane, leading to leakage of intracellular contents and eventual cell death. In addition, AuNCs have been shown to increase the concentration of reactive oxygen species (ROS) in bacteria and interrupt other metabolic pathways. ${ }^{42}$

Common AuNCs are generally composed of a thiolate-coordinated ligand shell around the gold core, largely due to the relative ease in preparation and the high stability of thiolated AuNCs. ${ }^{29}$ In contrast, reports of phosphine-functionalized AuNCs for antibacterial use are rare. However, phosphine-coordinated $\mathrm{Au}^{\mathrm{I}}$-complexes are relatively active and have been proposed as potential candidates as antimalarial, anticancer, and antiviral agents. ${ }^{43,44}$ For example, Jahnen-Dechent and coworkers reported the synthesis of "magic number" $\mathrm{Au}_{55}$ $(1.4 \mathrm{~nm})$ and $\mathrm{Au}_{8}(0.8 \mathrm{~nm})$ nanoclusters functionalized with triphenylphosphine monosulfonate (TPPMS). ${ }^{45}$ Both AuNCs were toxic to Gram-positive $S$. aureus and S. epidermidis (minimal inhibitory concentration (MIC): $25 \mu \mathrm{M}$ ) but not to Gram-negative E. coli or P. aeruginosa strains (MIC $>400 \mu \mathrm{M}$ ). However, thiolate-capped AuNCs of similar size (1.9 nm, AuroVist Nanoprobes 1102A) were inactive against all tested strains, suggesting higher activity for AuNCs carrying more labile phosphine ligands. Proposed MOAs include AuNC-mediated oxidative stress and the loss of membrane permeability. ${ }^{45}$ The smaller $0.8 \mathrm{~nm}$ AuNCs caused significantly greater bacterial inhibition than the larger $1.4 \mathrm{~nm}$ AuNCs.

In this study, we designed AuNCs based on the structural motif of auranofin, consisting of an $\mathrm{Au}$ core coordinated with a tetraacetylated 1-thioglucose and a phosphine ligand. We hypothesized that these AuNCs would harness the properties of both auranofin and AuNCs to afford enhanced antimicrobial activity. In addition, through optimization of the ratio of thiolate/phosphine ligands on the AuNCs, several critical parameters could be controlled and evaluated, including bacterial Au uptake, antimicrobial activity, and mammalian cytotoxicity.

\section{RESULTS}

\section{Synthesis of AuNCs}

Phosphine-functionalized AuNCs are typically chosen as precursors for the synthesis of 
clusters with mixed phosphine/thiolate ligand shells owing to the favorable replacement of phosphine ligands with thiolates. ${ }^{46}$ Of the potential clusters, " $\mathrm{Au}_{55}$ " $(1.4 \mathrm{~nm})$ was initially considered a candidate due to its demonstrated activity against Gram-positive bacteria, such as $S$. aureus and $S$. epidermidis. ${ }^{45}$ However, the synthesis of this cluster involves the use of pyrophoric diborane gas, ${ }^{47}$ and an improved synthesis protocol developed by Hutchison and coworkers was instead adopted. ${ }^{48,49}$ In this protocol, $\mathrm{HAuCl}_{4}$ is reduced by $\mathrm{NaBH}_{4}$ in the presence of $\mathrm{PPh}_{3}$ in a biphasic water/toluene solvent using tetraoctylammonium bromide (TOAB) as a phase transfer catalyst, yielding $\sim 1.5 \mathrm{~nm}$ AuNCs with a molecular formula of $\mathrm{Au}_{101}\left(\mathrm{PPh}_{3}\right)_{21} \mathrm{Cl}_{5}\left(\mathbf{1}\right.$, Figure 2a) as determined by XPS. Since auranofin possesses a $\mathrm{PEt}_{3}$ ligand, exchange with $\mathrm{PEt}_{3}$ was also attempted. However, the reaction resulted in a black product that was insoluble in organic or aqueous solvents, while yielding a clear solution in aqua regia, indicative of $\mathrm{Au}^{0}$ formation. ${ }^{48}$ Excess $\mathrm{PEt}_{3}$ also resulted in decomposition of cluster 1. The difficulty of ligand exchange with $\mathrm{PEt}_{3}$ is consistent with the scarcity of reported small aliphatic phosphine-functionalized clusters, ${ }^{50}$ despite multiple reports of AuNCs possessing aromatic, bidentate, and alicyclic phosphine ligands. ${ }^{51}$ More sterically encumbered ligands are furthermore known to provide better stabilization of nanoclusters in solution. ${ }^{52,53}$ Consequently, we designed AuNCs passivated by aromatic phosphines and several candidates were prepared to evaluate the effects of glycosylation, aqueous solubility, and cluster size on the antibacterial activity (Figure 2).

a)

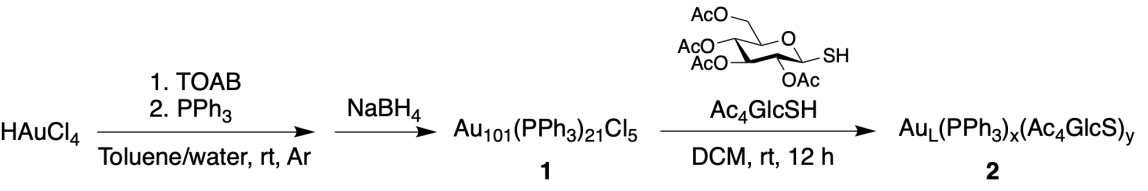

b)

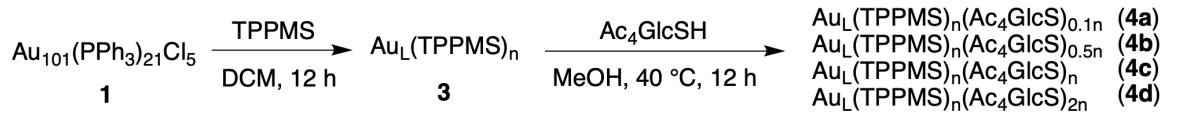

c)

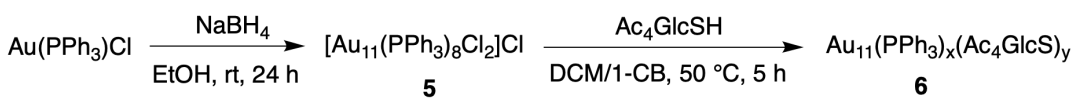

d)

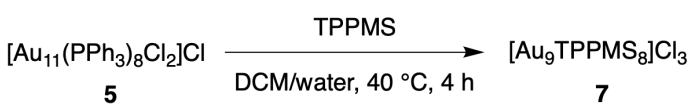

e)

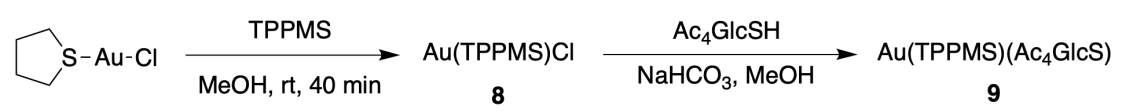

Figure 2: Synthesis of AuNCs and complexes: (a) $A u_{L}\left(P P h_{3}\right)_{x}\left(A c_{4} G l c S\right)_{y}$ (2), (b) $A u_{L}(T P P M S)_{n}\left(A c_{4} G l c S\right)_{0.1-2 n}$ $(4 \boldsymbol{a}-\mathbf{4 d}), \quad$ (c) $A u_{11}\left(\mathrm{PPh}_{3}\right)_{x}\left(A c_{4} G l c S\right)_{y} \quad$ (6), (d) $A u_{9}(T P P M S)_{8} C l_{3} \quad$ (7), (e) $A u(T P P M S)\left(A c_{4} G l c S\right) \quad$ (9). 1-CB =1-chlorobutane.

Consistent with the literature report, ${ }^{48}$ the ${ }^{1} \mathrm{H}$ NMR spectrum of cluster $\mathbf{1}$ showed broadened $\mathrm{PPh}_{3}$ signals centered at $\sim 7.2 \mathrm{ppm}$ (Figure S15) as a result of the cluster formation and environmental heterogeneity of the ligands. ${ }^{54,55} \mathrm{~A}$ byproduct of the synthesis, $\mathrm{Au}\left(\mathrm{PPh}_{3}\right) \mathrm{Cl}$, was observed as sharper signals at 7.51-7.58 ppm and could not be completely removed due to the metastability of the AuNC. ${ }^{48}$ 
Glycosylation of cluster 1 was performed in dichloromethane (DCM) using 16 equivalents of $\mathrm{Ac}_{4} \mathrm{GlcSH}$, synthesized according to a literature protocol (Figure $\underline{\mathbf{2}} \mathbf{a}$ ) ${ }^{56}$ After stirring at ambient temperature for $12 \mathrm{~h}$, complete consumption of $\mathrm{Ac}_{4} \mathrm{GlcSH}$ was confirmed. The solution was concentrated and purified by size exclusion chromatography to give cluster $\mathbf{2}$, denoted as $\mathrm{Au}_{\mathrm{L}}\left(\mathrm{PPh}_{3}\right)_{\mathrm{x}}\left(\mathrm{Ac}_{4} \mathrm{GlcS}\right)_{\mathrm{y}}$. The presence of the $\mathrm{Ac}_{4} \mathrm{GlcS}$ and $\mathrm{PPh}_{3}$ ligands was supported by the prominent acetyl resonance at $\sim 2 \mathrm{ppm}$ and the $\mathrm{PPh}_{3}$ signals at $\sim 7.5 \mathrm{ppm}$ in the ${ }^{1} \mathrm{H}$ NMR spectrum (Figure $\left.\mathrm{S} 16\right)$. The byproduct $\mathrm{Au}\left(\mathrm{PPh}_{3}\right) \mathrm{Cl}$ was still present in cluster 2, although at a lower concentration compared to the starting cluster $\mathbf{1}$. Cluster 2 was slightly lighter in color, more soluble in alcohols, and more stable in $\mathrm{DCM}$ or $\mathrm{CHCl}_{3}$ compared to cluster $\mathbf{1}$, which rapidly decomposed to $\mathrm{Au}^{0}$ within a few hours. ${ }^{48}$

Water-soluble analogues 4a-4d were synthesized by first replacing $\mathrm{PPh}_{3}$ in cluster 1 with sodium triphenylphosphine-3-sulfonate (TPPMS), prepared by sulfonation of $\mathrm{PPh}_{3}$ using oleum (Figure 2 $2 \mathbf{b}) .{ }^{57}$ A 50 -molar excess of TPPMS in a biphasic water/DCM solution resulted in the complete transfer of cluster 1 to the aqueous layer after $12 \mathrm{~h}$ at room temperature. Purification by size exclusion chromatography gave cluster $\mathbf{3}$ as a black powder. No free TPPMS ligand (-6 ppm), its oxide (37 ppm), or the $\mathrm{Au}^{\mathrm{I}}$ impurity (32 ppm) was observed by ${ }^{31} \mathrm{P}$ NMR. Similar to cluster 1, the aromatic proton resonances of cluster 3 were significantly broadened in the ${ }^{1} \mathrm{H}$ NMR spectrum (Figure S17). Cluster 3 proved more stable than cluster 1 and could be heated in aqueous solution with no decomposition to $\mathrm{Au}^{0}$. Multiple freeze-drying cycles did not cause any discernible change in the ${ }^{1} \mathrm{H}$ NMR spectrum either. The improved colloidal stability is a result of electrostatic stabilization by replacing neutral with charged ligands and has also been observed in other nanoparticle systems. ${ }^{58}$

Glycosylation of cluster 3 was carried out using different equivalents of $\mathrm{Ac}_{4} \mathrm{GlcSH}$, resulting in mixed-ligand AuNCs 4a-4d with different carbohydrate/phosphine ratios. Cluster 3 was mixed with $\mathrm{Ac}_{4} \mathrm{GlcSH}(3.2,0.8,0.2$, and $0.05 \mathrm{w} / \mathrm{w})$ and heated at $40{ }^{\circ} \mathrm{C}$ in $\mathrm{MeOH}$ for $12 \mathrm{~h}$, at which time TLC confirmed that no free $\mathrm{Ac}_{4} \mathrm{GlcSH}$ was present. The clusters were purified by size exclusion chromatography to give wispy dark brown solids. The ${ }^{1} \mathrm{H}$ NMR signals of the ligands were broadened and only the peaks of the acetyl groups were distinguishable at $\sim 2 \mathrm{ppm}$ (Figure S18). The higher the $\mathrm{Ac}_{4} \mathrm{GlcSH}$ load, the more the TPPMS was replaced in the product (Figure S19). From the peak integrations of the acetyl and aromatic protons, the ratio of the $\mathrm{Ac}_{4} \mathrm{GlcS}$ and TPPMS ligands in AuNCs 4a-4d was estimated to be $2,1,0.5$, and 0.1 (Table $\mathrm{S} 1$ ). Increased glycosylation resulted in reduced solubility in water and higher solubility in alcohols.

The size of cluster $\mathbf{4 b}$ was analyzed by TEM (Figure S3). From a total of 561 particles, the particle core diameter was determined to be $1.6 \pm 0.3 \mathrm{~nm}$, concurring with literature reports that the ligand exchange process resulted in minimal changes in cluster size. ${ }^{49}$ This was further supported by the UV-Vis absorption spectra of clusters $\mathbf{1}, \mathbf{3}$, and $\mathbf{4 b}$, showing no significant plasmon bands or absorptions resulting from quantized transitions as expected for smaller AuNCs (Figures S22-S26). ${ }^{55}$

The smaller cluster $\mathrm{Au}_{11}\left(\mathrm{Ac}_{4} \mathrm{GlcS}\right)_{\mathrm{x}}\left(\mathrm{PPh}_{3}\right)_{\mathrm{y}} \quad(6)$ was synthesized from cluster $\left[\mathrm{Au}_{11}\left(\mathrm{PPh}_{3}\right)_{8} \mathrm{Cl}_{2}\right] \mathrm{Cl}$ (5) through ligand exchange (Figure 2 $\mathbf{c}$ ). The parent cluster 5 was accessed using a literature procedure, ${ }^{59}$ yielding a red-colored product that matched the ${ }^{1} \mathrm{H}$ and ${ }^{31} \mathrm{P}$ NMR data reported (Figures S19-S20). Although being $\mathrm{PPh}_{3}$-capped, this cluster is considerably more stable than cluster 1 , requiring elevated temperature to undergo ligand exchange. ${ }^{60}$ The reduced exchangeability was attributed to the reduction in core size, where the steric hindrance around the core prevented the associative exchange process involving the incoming ligands and the Au core. ${ }^{61}$ To obtain a mixed-ligand shell of $\mathrm{PPh}_{3}$ and $\mathrm{Ac}_{4} \mathrm{GlcS}$, cluster 5 was allowed to react with 11 equivalents of $\mathrm{Ac}_{4} \mathrm{GlcSH}$ in DCM/1-chlorobutane at 
$50{ }^{\circ} \mathrm{C}$, yielding $\mathrm{Au}_{11}\left(\mathrm{Ac}_{4} \mathrm{GlcS}\right)_{\mathrm{x}}\left(\mathrm{PPh}_{3}\right)_{\mathrm{y}}(6)$ as a brown solid after $5 \mathrm{~h}$.

Ligand exchange at cluster 5 gave AuNC $\left[\mathrm{Au}_{9}(\mathrm{TPPMS})_{8}\right] \mathrm{Cl}_{3}$ (7, Figure 2d). Attempts to exchange TPPMS with $\mathrm{Ac}_{4} \mathrm{GlcSH}$ in methanol were unsuccessful despite the use of excess amounts of carbohydrate (up to 200 equiv.) and elevated temperature (up to $60{ }^{\circ} \mathrm{C}$ ). In these reactions, a white precipitate was formed that consisted of TPPMS oxide (37 ppm, ${ }^{31} \mathrm{P}$ NMR) and $\mathrm{Au}(\mathrm{TPPMS}) \mathrm{Cl}\left(32 \mathrm{ppm},{ }^{31} \mathrm{P} \mathrm{NMR}\right)$.

$\mathrm{An} \mathrm{Au}^{\mathrm{I}}$ complex analogue of the clusters, $\mathrm{Au}(\mathrm{TPPMS})\left(\mathrm{Ac}_{4} \mathrm{GlcS}\right)(9)$, was synthesized by ligand exchange from the known $\mathrm{Au}^{\mathrm{I}}$ complex $\mathrm{Au}(\mathrm{TPPMS}) \mathrm{Cl}$ (8, Figure 2e), synthesized following a literature protocol. ${ }^{62}$ Base-promoted replacement of the $\mathrm{Cl}$ ligand in complex $\mathbf{8}$ with the $\mathrm{Ac}_{4} \mathrm{GlcSH}$ gave cluster 9 . Both complexes were soluble in water.

\section{Antibacterial activity depends on ligand shell and cluster size}

The MICs of the prepared clusters and complexes were first evaluated against a panel of antibiotic-resistant ESKAPE pathogens consisting of Gram-positive (Staphylococcus aureus, Enterococcus faecalis) and Gram-negative bacterial strains (Klebsiella pneumoniae, Acinetobacter baumannii, Pseudomonas aeruginosa, Enterobacter cloacae), as well as a Gram-negative strain (E. coli ATCC 25922) used as quality control (Table 1). The minimal bactericidal concentrations (MBCs) were also obtained for those entities showing MICs of $<130 \mu \mathrm{g} / \mathrm{mL}[\mathrm{Au}]$. Consistent with auranofin, the clusters were more active against Grampositive bacteria ( $S$. aureus and E. faecalis) than the Gram-negative strains. The larger watersoluble clusters $\mathbf{4 b}$ and $\mathbf{3}$ were active against Gram-negative strains, including the multidrugresistant A. baumannii (MIC/MBC $=20 / 40 \mu \mathrm{g} / \mathrm{mL}$ ) and $P$. aeruginosa NCTC13437 $(\mathrm{MIC} / \mathrm{MBC}=20 / 20 \mu \mathrm{g} / \mathrm{mL}$ ). The activity against $P$. aeruginosa was higher than that of auranofin $(\mathrm{MIC} / \mathrm{MBC}=74 / 74 \mu \mathrm{g} / \mathrm{mL}[\mathrm{Au}])$.

Table 1: $M I C^{a}(M B C)\left(\mu g / m L[A u]^{b}\right)$ of AuNCs and Aut-complexes against ESKAPE pathogens and E. coli ATCC 25922

\begin{tabular}{|c|c|c|c|c|c|c|c|}
\hline & $\begin{array}{l}\text { A. baumannii } \\
\text { NCTC } \\
13420\end{array}$ & $\begin{array}{l}\text { P. aeruginosa } \\
\text { NCTC } \\
13437\end{array}$ & $\begin{array}{l}\text { E. cloacae } \\
\text { NCTC } \\
13405\end{array}$ & $\begin{array}{c}\text { K. pneumoniae } \\
\text { ATCC } \\
700603\end{array}$ & $\begin{array}{c}\text { S. aureus } \\
\text { USA300 } \\
\text { JE2 }\end{array}$ & $\begin{array}{c}\text { E. faecalis } \\
\text { ATCC } \\
51299\end{array}$ & $\begin{array}{l}\text { E. coli } \\
\text { ATCC } \\
25922\end{array}$ \\
\hline $\mathrm{Au}_{101}\left(\mathrm{PPh}_{3}\right)_{21} \mathrm{Cl}_{5}(\mathbf{1})^{\mathrm{c}}$ & $50(50)$ & $>200$ & $>200$ & $>200$ & $3.2(3.2)$ & $25(25)$ & $>200$ \\
\hline $\mathrm{Au}_{101}\left(\mathrm{PPh}_{3}\right)_{\mathrm{x}}\left(\mathrm{Ac}_{4} \mathrm{GlcS}\right)_{\mathrm{y}}(2)^{\mathrm{c}}$ & $>200$ & $>200$ & $>200$ & $>200$ & $3.2(3.2)$ & $12(12)$ & $>200$ \\
\hline $\mathrm{Au}_{\mathrm{L}}(\mathrm{TPPMS})_{\mathrm{n}}(\mathbf{3})^{\mathrm{d}}$ & $20(40)$ & $20(20)$ & $>160$ & $>160$ & $1.4(1.4)$ & $5.1(5.1)$ & 160 \\
\hline $\mathrm{Au}_{\mathrm{L}}(\mathrm{TPPMS})_{\mathrm{n}}\left(\mathrm{Ac}_{4} \mathrm{GlcS}\right)_{0.5 \mathrm{n}}(\mathbf{4 b})^{\mathrm{d}}$ & $20(41)$ & $20(20)$ & $>160$ & $>160$ & $1.2(1.2)$ & $5.1(5.1)$ & $>160$ \\
\hline$\left[\mathrm{Au}_{11}\left(\mathrm{PPh}_{3}\right)_{8} \mathrm{Cl}_{2}\right] \mathrm{Cl}(\mathbf{5})^{\mathrm{c}}$ & $>130$ & $>130$ & $>130$ & $>130$ & $3.9(3.9)$ & $>130$ & $>130$ \\
\hline $\mathrm{Au}_{11}\left(\mathrm{PPh}_{3}\right)_{\mathrm{x}}\left(\mathrm{Ac}_{4} \mathrm{GlcS}\right)_{\mathrm{y}}(6)^{\mathrm{c}}$ & $>130$ & $>130$ & $>130$ & $>130$ & $3.9(3.9)$ & $>130$ & $>130$ \\
\hline$\left[\mathrm{Au}_{9}(\mathrm{TPPMS})_{8}\right] \mathrm{Cl}_{3}(7)^{\mathrm{d}}$ & $>92$ & $>92$ & $>92$ & $>92$ & $1.4(1.4)$ & $1.4(1.4)$ & $>92$ \\
\hline Auranofin ${ }^{63}$ & $9.3(9.3)$ & $74(74)$ & $37(37)$ & $74(74)$ & $\begin{array}{l}0.0079 \\
(0.018)\end{array}$ & $\begin{array}{c}0.039 \\
(0.079)\end{array}$ & $4.7(4.7)$ \\
\hline
\end{tabular}

aPerformed at the Antimicrobial Screening Facility, Warwick University, UK; all tests repeated twice; ciprofloxacin and teicoplanin included as quality controls. ${ }^{\mathrm{b}}[\mathrm{Au}]$ in AuNCs determined by inductively coupled plasma mass spectrometry (ICPMS). ${ }^{c}$ Dissolved in DMSO. ${ }^{\mathrm{d}}$ Dissolved in water.

The antipseudomonal activity of the water-soluble TPPMS-capped AuNCs and $\mathrm{Au}^{\mathrm{I}}$ complexes was further tested against the laboratory strain $P$. aeruginosa PAO1 and the quality control strain $P$. aeruginosa ATCC 27853. The impact of glycosylation on the antibacterial activity was probed using clusters 4a-4d and the cluster size effect was evaluated by comparing cluster 3 with $\mathrm{Au}_{9}$-cluster 7, and $\mathrm{Au}^{\mathrm{I}}$ complex 8. Cluster 4b, having a TPPMS:Ac ${ }_{4}$ GlcS ratio of 1:2, again showed the highest activity with MICs of $20 \mu \mathrm{g} / \mathrm{mL}$ for both Pseudomonas strains (Table 2). Either a higher or lower degree of glycosylation resulted in lower activity. Comparing the clusters having the same TPPMS ligand, the larger cluster 3 was more active than the smaller $\mathrm{Au}_{9}$-cluster 7 . 


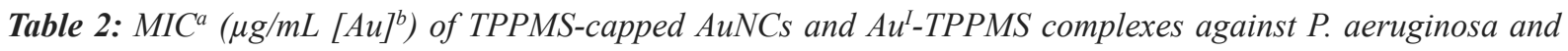
S. aureus (MRSA).

\begin{tabular}{|c|c|c|c|}
\hline & $\begin{array}{l}\text { P. aeruginosa } \\
\text { PAO1 }\end{array}$ & $\begin{array}{c}P . \text { aeruginosa } \\
\text { ATCC } 27853\end{array}$ & $\begin{array}{l}P . \text { aeruginosa } \\
{\text { NCTC } 13437^{\circ}}^{-}\end{array}$ \\
\hline $\mathrm{Au}_{\mathrm{L}}(\mathrm{TPPMS})_{\mathrm{n}}\left(\mathrm{Ac}_{4} \mathrm{GlcS}\right)_{0.1 \mathrm{n}}(\mathbf{4 a})$ & 56 & 56 & - \\
\hline $\mathrm{Au}_{\mathrm{L}}(\mathrm{TPPMS})_{\mathrm{n}}\left(\mathrm{Ac}_{4} \mathrm{GlcS}\right)_{0.5 \mathrm{n}}(\mathbf{4 b})$ & 20 & 20 & 20 \\
\hline $\mathrm{Au}_{\mathrm{L}}(\mathrm{TPPMS})_{\mathrm{n}}\left(\mathrm{Ac}_{4} \mathrm{GlcS}\right)_{\mathrm{n}}(\mathbf{4 c})$ & 47 & 93 & - \\
\hline $\mathrm{Au}_{\mathrm{L}}(\mathrm{TPPMS})_{\mathrm{n}}\left(\mathrm{Ac}_{4} \mathrm{GlcS}\right)_{2 \mathrm{n}}(\mathbf{4 d})$ & $>100$ & $>100$ & - \\
\hline $\mathrm{Au}_{\mathrm{L}}(\mathrm{TPPMS})_{\mathrm{n}}(\mathbf{3})$ & 20 & 40 & 20 \\
\hline$\left[\mathrm{Au}_{9}(\mathrm{TPPMS})_{8}\right] \mathrm{Cl}_{3}(7)$ & 46 & $>46$ & $>92$ \\
\hline $\mathrm{Au}(\mathrm{TPPMS}) \mathrm{Cl}(\mathbf{8})$ & 21 & 40 & - \\
\hline $\mathrm{Au}(\mathrm{TPPMS})\left(\mathrm{Ac}_{4} \mathrm{GlcS}\right)(\mathbf{9})$ & $>27$ & $>27$ & - \\
\hline
\end{tabular}

${ }^{a}$ All compounds dissolved in water; MIC values represent mode of 4 trials; ciprofloxacin and gentamicin included as quality

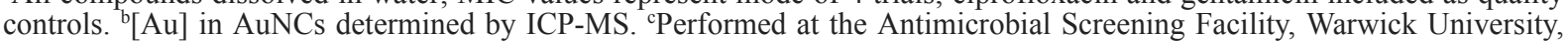
UK; repeated twice.

\section{Clusters display lower mammalian cell toxicity than auranofin}

The effectiveness and safety of a drug can be evaluated by the selectivity index (SI), expressed as the ratio of cytotoxicity and activity. Auranofin has a half-maximal cytotoxic concentration $\left(\mathrm{CC}_{50}\right)$ of $2.2 \pm 0.4 \mu \mathrm{g} / \mathrm{mL}$ against $\mathrm{A} 549$ human lung cancer cells (ATCC CCL-185). As auranofin has low activity against $P$. aeruginosa, this leads to a low SI of $0.029\left(=\mathrm{CC}_{50} / \mathrm{MIC}\right.$, Table $\left.\underline{3}\right)$. Both the glycosylated cluster $4 \mathbf{b}$ (Figure S4) and the nonglycosylated cluster 3 (Figure S5) were less toxic than auranofin towards A549 cells, having a $\mathrm{CC}_{50}$ of $53 \pm 7 \mu \mathrm{g} / \mathrm{mL}$ and $42 \pm 10 \mu \mathrm{g} / \mathrm{mL}$, respectively (Table $\underline{\mathbf{3}}$ ). The SI of cluster $\mathbf{4 b}$ $(\mathrm{SI}=2.6)$ was slightly higher than for cluster $3(\mathrm{SI}=2.1)$, and the two clusters were 90 and 72 times better than auranofin.

Table 3: $C_{50}{ }^{a}\left(\mu \mathrm{g} / \mathrm{mL}[\mathrm{Au}]^{b}\right)$ against A549 cells and MIC against P. aeruginosa of $A u_{L} N C s$ and auranofin.

\begin{tabular}{lccc}
\hline & $\begin{array}{c}\text { A549 } \\
\text { ATCC CCL-185 }\end{array}$ & $\begin{array}{c}\text { P. aeruginosa } \\
\text { NCTC13437 }\end{array}$ & Selectivity index \\
\hline $\mathrm{Au}_{\mathrm{L}}(\mathrm{TPPMS})_{\mathrm{n}}\left(\mathrm{Ac}_{4} \mathrm{GlcS}\right)_{0.5 \mathrm{n}}(\mathbf{4 b})$ & $53 \pm 7$ & 20 & 2.6 \\
$\mathrm{Au}_{\mathrm{L}}(\mathrm{TPPMS})_{\mathrm{n}}(\mathbf{3})$ & $42 \pm 10$ & 20 & 2.1 \\
$\mathrm{Auranofin}$ & $2.2 \pm 0.4$ & 74 & 0.029 \\
\hline
\end{tabular}

${ }^{\mathrm{a} M e a n} \pm \mathrm{SD}$ of two trials, each done in triplicate. ${ }^{\mathrm{b}}[\mathrm{Au}]$ in AuNCs determined by ICP-MS.

\section{AuNCs show high cellular uptake}

The activity of most antibiotics against $P$. aeruginosa and other Gram-negative bacteria is to a large extent determined by their ability to overcome the OM barrier and accumulate inside bacteria. ${ }^{64,65}$ This uptake efficiency could be a source of the observed disparity in bacterial killing between different gold clusters and complexes. To test this, uptake experiments were carried out by analyzing the intracellular gold content using ICP-MS. Bacteria were incubated with the different gold compounds for $4 \mathrm{~h}$, washed with PBS to remove excess compounds, digested with aqua regia, and the Au content measured. Candidates include TPPMS-capped cluster $\mathbf{3}, \mathrm{Au}_{9}$-cluster $\mathbf{7}$ and $\mathrm{Au}^{\mathrm{I}}$ complex $\mathbf{8}$ to test the size-dependent uptake, and cluster $\mathbf{4 b}$ for the impact of glycosylation (Figure $\underline{\mathbf{3}}$ ). A significantly higher uptake was observed with the larger clusters $\mathbf{4 b}(20 \pm 3.5 \%)$ and $\mathbf{3}(26 \pm 1.9 \%)$ compared to the smaller cluster 7 $(3.7 \pm 3.6 \%)$ and the $\mathrm{Au}^{\mathrm{I}}$ complex $8(6.3 \pm 5.5 \%)$. 


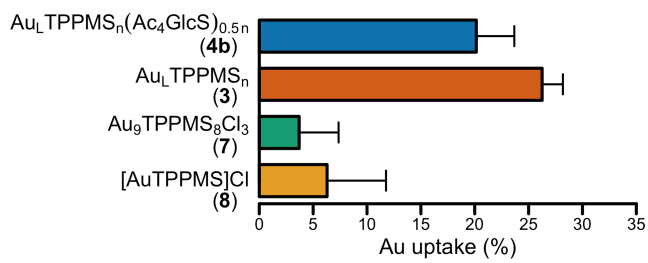

Figure 3: Uptake of Au of AuNCs and Au complex by P. aeruginosa PAO1. Each data was an average of 3 independent trials, presented as mean $\pm S D$. \%Au uptake is the percent of Au taken up by bacteria vs. amount initially added. All data were adjusted to a final bacteria count of $4.0 \times 10^{9} \mathrm{CFU} / \mathrm{mL}$.

The water-soluble TPPMS-capped AuNCs $\mathbf{4 b}$ and $\mathbf{3}$ were stable, showing no signs of disintegration in $\mathrm{D}_{2} \mathrm{O}$ for months. To further evaluate the stability, cluster $\mathbf{4 b}$ and $\mathrm{HAuCl}_{4}$ were dialyzed in PBS at $\mathrm{pH} 7.4$ and $35{ }^{\circ} \mathrm{C}$ across a 3,500 MWCO dialysis membrane. The dialysates were continuously sampled over $26 \mathrm{~h}$ and the Au contents were determined by ICPMS. The results show that less than $0.3 \%$ of the gold leached from the AuNC $\mathbf{4 b}$ through the membrane, whereas the control sample reached a maximum level of $97 \%$ after $8 \mathrm{~h}$ (Figure S4).

\section{Antibacterial activity of $\mathrm{Au}_{\mathrm{L}} \mathrm{NCs}$ is unaffected by extracellular proteins}

It has been reported that the antibacterial activity of auranofin can be antagonized by the presence of extracellular proteins in the growth medium. ${ }^{9}$ Proteins, such as serum albumin, can react with gold complexes, for example through interactions with cystein residues, thereby preventing the complexes to reach their bacterial targets. ${ }^{66,67}$ For instance, the MIC of auranofin against $M$. tuberculosis was reported to increase 20 times in normal versus minimal medium; a result associated with albumin-promoted inactivation. ${ }^{9}$ For this reason, we investigated the antibacterial activity of the Au clusters and complexes in M9 minimal salts medium, a buffered solution of salts supplemented with $0.4 \%$ glucose as the carbon source, and compared the results to nutrient-rich cation-adjusted Mueller-Hinton broth (CAMHB). As expected, the $\mathrm{Au}^{\mathrm{I}}$ complexes $\mathrm{Au}(\mathrm{TPPMS}) \mathrm{Cl}(\mathbf{8})$ and auranofin showed a 4-fold reduction in MIC in the M9 minimal medium compared to that in CAMHB (Table 4). However, the activities of clusters $\mathbf{4 b}, \mathbf{3}$, and $\mathbf{7}$ were unaffected, having the same MICs in both media.

Table 4: $M I C^{a}\left(\mu \mathrm{g} / \mathrm{mL}[\mathrm{Au}]^{b}\right)$ of Au clusters and complexes in $M 9$ minimal medium vs. nutrient-rich CAMHB.

\begin{tabular}{lccc}
\hline & M9 & CAMHB & MIC $_{\text {CAMHB }} / \mathbf{M I C}_{\mathbf{M 9}}$ \\
\hline $\mathrm{Au}_{\mathrm{L}}(\mathrm{TPPMS})_{\mathrm{n}}\left(\mathrm{Ac}_{4} \mathrm{GlcS}\right)_{0.5 \mathrm{n}} \mathbf{( 4 b )}$ & 20 & 20 & 1 \\
$\mathrm{Au}_{\mathrm{L}}(\mathrm{TPPMS})_{\mathrm{n}}(\mathbf{3})$ & 20 & 20 & 1 \\
{$\left[\mathrm{Au}_{9}(\mathrm{TPPMS})_{8}\right]_{\mathrm{Cl}}(\mathbf{7})$} & 46 & 46 & 1 \\
{$[\mathrm{AuTPPMS}] \mathrm{Cl}(\mathbf{8})$} & 5.3 & 21 & 4 \\
Auranofin & 19 & 74 & 4 \\
\hline
\end{tabular}

${ }^{\mathrm{a} E a c h}$ data repeated twice; ciprofloxacin and gentamicin included as quality controls. ${ }^{\mathrm{b}}[\mathrm{Au}]$ in AuNCs determined by ICPMS.

\section{AuNCs are unaffected by the OM barrier}

Since the OM barrier plays an important role in the cellular uptake and antibacterial activity against Gram-negative bacteria like $P$. aeruginosa, the ability of the clusters to cross the bacterial $\mathrm{OM}$ could explain the observed enhancement in the uptake and antimicrobial susceptibility. To shed further light on this, we measured the MICs of the clusters in the presence of colistin, a cationic antibiotic peptide that is believed to bind to 
lipopolysaccharides and phospholipids, displace $\mathrm{Ca}^{2+}$ and $\mathrm{Mg}^{2+}$, and generate pores in the bacterial OM. ${ }^{68,69}$ Antibiotics that are inactive against Gram-negative bacteria due to the OM barrier can be made active by colistin. ${ }^{27}$ Colistin was thus added at $0.25 \times \mathrm{MIC}$ $\left(\mathrm{MIC}_{\text {colistin }}=4 \mu \mathrm{g} / \mathrm{mL}\right.$ against $P$. aeruginosa PAO1) together with the Au clusters or complexes, and the MICs were measured. The MIC of Au complex 8 was improved 64-fold in the presence of colistin (Table 5). A slight 4-fold enhancement was observed for the smaller cluster 7, whereas no change in MIC was observed with the addition of colistin for cluster $\mathbf{4 b}$.

Table 5: $\mathrm{MIC}^{a}\left(\mu \mathrm{g} / \mathrm{mL}[\mathrm{Au}]^{b}\right)$ of Au clusters and complexes against P. aeruginosa PAOI with and without colistin.

\begin{tabular}{lccc}
\hline & MIC (w/o colistin) & MIC $(w /$ colistin) & Enhancement \\
\hline $\mathrm{Au}_{\mathrm{L}}(\mathrm{TPPMS})_{\mathrm{n}}\left(\mathrm{Ac}_{4} \mathrm{GlcS}\right)_{0.5 \mathrm{n}}(\mathbf{4 b})$ & 20 & 20 & 1 \\
$\mathrm{Au}_{\mathrm{L}}(\mathrm{TPPMS})_{\mathrm{n}}(\mathbf{3})$ & 20 & $10 / 20$ & $1-2$ \\
{$\left[\mathrm{Au}_{9}(\mathrm{TPPMS})_{8}\right] \mathrm{Cl}_{3}(\mathbf{7})$} & 46 & 11 & 4 \\
{$[\mathrm{AuTPPMS}] \mathrm{Cl}(\mathbf{8})$} & 21 & 0.33 & 64 \\
\hline
\end{tabular}

${ }^{a}$ Each data repeated twice; ciprofloxacin and gentamicin included as quality controls. ${ }^{b}[\mathrm{Au}]$ in AuNCs determined by ICPMS. ${ }^{c}$ Enhancement $=$ MIC (w/o colistin)/MIC (w/ colistin).

\section{AuNCs induce moderate genotoxicity}

AuNCs can induce genotoxicity in bacteria, damaging DNA by AuNC-generated ROS species or by direct binding. ${ }^{70}$ Damage to bacterial DNA can lead to double-stranded breaks (DSBs), which can be quantified using DNA repair proteins fused to a fluorescent protein, such as the yellow fluorescent protein (YFP). ${ }^{71}$ We used the recombinant E. coli SX1220 strain, capable of expressing the YFP-tagged RecN repair protein in response to DSBs and resulting in the appearance of yellow fluorescence in a concentration-dependent fashion. ${ }^{72}$ These YFP-tagged RecN fusion proteins usually appear as concentrated assemblies in bacteria having DSBs. ${ }^{73}$ In our experiment, E. coli SX1220 was incubated with the Au cluster or complex at a sub-MIC concentration $(8 \mu \mathrm{g} / \mathrm{mL})$ for $1 \mathrm{~h}$. The cells were washed with PBS, stained with the bluefluorescent nucleic acid-staining dye 4',6-diamidino-2-phenylindole (DAPI), and then fixed for imaging by laser-scanning confocal microscopy (LSCM). Cells expressing the RecN-YFP fusion protein displayed green emission (overlap between yellow and blue), thereby indicating DSB generation (Figure 4). DSBs were observed for all AuNCs as shown by the green fluorescence emitted, albeit to a low extent compared to the controls, and the images showed mostly DAPI staining with little YFP fluorescence.

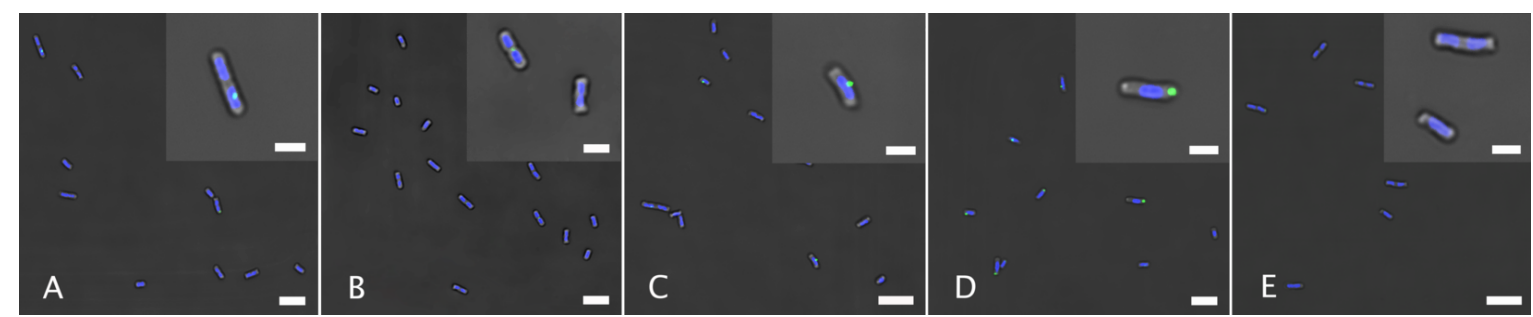

Figure 4: LSCM images of $E$. coli $S X 1220$ treated with (A) $\left[\mathrm{Au}_{9}(T P P M S)_{8}\right] C l_{3} \quad$ (7), (B) $A u_{L}(T P P M S)_{n}\left(A c_{4} G l c S\right)_{0.5 n}$ (4b), (C) Au $u_{L}(T P P M S)_{n}(3)$, (D) ciprofloxacin, and (E) buffer only as the control. Scale bars: $5 \mu \mathrm{m}$. Insets are enlarged regions of each panel, scale bars: $2 \mu \mathrm{m}$. The blue DAPI-stained bacteria show the cells in a given focal plane. Overlaps with the yellow RecN-YFP fusion proteins gave green, with higher intensity indicating more DSBs.

The relative number of expressed RecN centers per cell was estimated (Figure 6), showing 
$18 \pm 2.6 \%$ for cluster $\mathbf{4 b}, 33 \pm 3.5 \%$ for cluster $3,22 \pm 4.3 \%$ for cluster 7 , and $19 \pm 3.6 \%$ for $\mathrm{Au}^{\mathrm{I}}$ complex 8. To put these results in context, a series of control samples were tested. Bacteria only gave a low RecN expression of $12 \pm 9.7 \%$. Colistin, an antibiotic that causes cell death through mechanisms other than direct DNA damage, ${ }^{74}$ gave a similar low RecN expression. Even at a high colistin concentration of $8 \times \mathrm{MIC}(8 \mu \mathrm{g} / \mathrm{mL})$, the RecN-YFP expression was still low $(14 \pm 8.9 \%)$. On the other hand, ciprofloxacin, an antibiotic known to generate DNA damage by inhibiting bacterial DNA topoisomerase IV and DNA gyrase, ${ }^{75-77}$ gave the most DSBs, with an expression of $138 \pm 42 \%$. Hydrogen peroxide was furthermore included to evaluate any potential DSBs caused by oxidative stress. ${ }^{77}$ Cells treated with $30 \mathrm{mM} \mathrm{H}_{2} \mathrm{O}_{2}$ led to a relatively low RecN-YFP expression of $28 \pm 5.4 \%$.

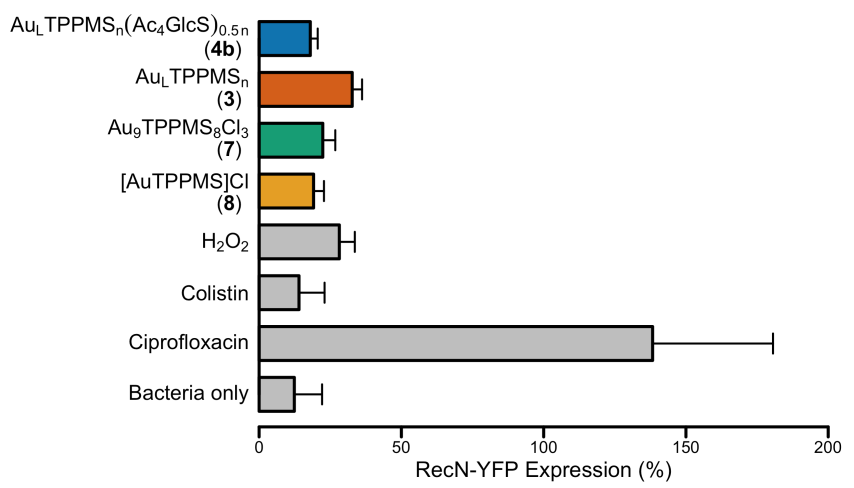

Figure 5: Percent (\%) RecN-YFP expression of E. coli SX1220 treated with different compounds and controls. DAPI channel assigned to total bacterial cell counts and YFP channel to total RecN centers (cf. Figures S6-S7). Data represent mean $\pm S D$ from analyzing 3-6 confocal images. Cumulative cell count per sample: 107-210.

\section{AuNCs are weaker inhibitors of TrxR than auranofin}

To assess whether the disruption of intracellular redox homeostasis could be a mode of antibacterial action of AuNCs, inhibition assays were performed using the thioredoxin/thioredoxin-reductase system (Trx/TrxR). TrxR reduces the disulfide bond at the Trx active site in the presence of NADPH, facilitating the reduction of intracellular thiols to maintain the redox balance. ${ }^{78}$ Auranofin and other $\mathrm{Au}^{\mathrm{I}}$ complexes are known to inhibit this enzyme, putatively through interaction with the S-Se active site, and thereby suppress the activity of Trx. ${ }^{75,76,79}$ This inhibition then results in unchecked oxidative stress and ultimate cell death. The in vitro inhibition assays were conducted using the E. coli TrxR in the presence of Ellman's reagent 5,5'-dithiobis(2-nitrobenzoic acid) (DTNB), which upon reduction by Trx generates colored 2-nitro-5-thiobenzoate $\left(\lambda_{\max }: 412 \mathrm{~nm}\right)$. The TrxR inhibition was estimated by following the rate of DTNB reduction spectrophotometrically in the presence of Au clusters and complexes. The MICs of these Au clusters and complexes against E. coli ATCC 25922 were furthermore recorded for comparison. Auranofin is a strong inhibitor of E. coli TrxR, giving an $\mathrm{IC}_{50}$ of $0.0045 \pm 0.006 \mu \mathrm{g} / \mathrm{mL}$ [Au]) (Table $\underline{6}$ ). Au complex 8 showed $\sim 12$ times weaker inhibition than auranofin. The clusters showed considerably lower degrees of inhibition, where AuNC 4b $\left(\mathrm{IC}_{50}: 2.4 \pm 0.4 \mu \mathrm{g} / \mathrm{mL}[\mathrm{Au}]\right)$ showed a $>500$ times higher $\mathrm{IC}_{50}$-value than auranofin. The AuNCs 3 and 7 displayed slightly higher inhibitory activity compared to cluster $\mathbf{4 b}$. 
Table 6: IC ${ }_{50}$ of Au clusters and complexes against E. coli TrxR and MIC against E. coli ATCC 25922.

\begin{tabular}{lcc}
\hline & IC $_{\mathbf{5 0}}(\boldsymbol{\mu g} / \mathbf{m L ~} \mathbf{A u})^{\mathbf{a}}$ & $\mathbf{M I C}(\boldsymbol{\mu g} / \mathbf{m L}[\mathbf{A u}])$ \\
\hline $\mathrm{Au}_{\mathrm{L}}(\mathrm{TPPMS})_{\mathrm{n}}\left(\mathrm{Ac}_{4} \mathrm{GlcS}\right)_{0.5 \mathrm{n}}(\mathbf{4 b})$ & $2.4 \pm 0.4$ & 20 \\
$\mathrm{Au}_{\mathrm{L}}(\mathrm{TPPMS})_{\mathrm{n}}(\mathbf{3})$ & $1.2 \pm 0.6$ & 40 \\
{$\left[\mathrm{Au}_{9}(\mathrm{TPPMS})_{8}\right] \mathrm{Cl}_{3}(\mathbf{7})$} & $0.69 \pm 0.4$ & $>46$ \\
{$[\mathrm{AuTPPMS}] \mathrm{Cl}(\mathbf{8})$} & $0.053 \pm 0.02$ & 21 \\
Auranofin & $0.0045 \pm 0.006$ & 4.7 \\
\hline
\end{tabular}

${ }^{\mathrm{a}}$ Mean $\pm \mathrm{SD}$ of two independent measurements.

\section{Intracellular thiol depletion}

In addition to the Trx/TrxR system, Gram-negative bacteria also utilize the glutathione (GSH)-glutaredoxin (Grx) system to counteract the buildup of ROS within the cell. ${ }^{80}$ Analogous to Trx/TrxR, this NADPH-dependent process occurs through initial reduction of glutathione reductase (GR), followed by consequential reduction of intracellular GSH, Grx, and potential downstream disulfide reduction. ${ }^{80}$ Therefore, quantification of available thiols in the bacteria can indicate the general oxidative stress the bacteria are under, which includes both systems of thiol-disulfide regulation. ${ }^{81,82}$ To observe this effect, $P$. aeruginosa PAO1 was incubated with the Au clusters and complexes and the amount of free intracellular thiol was measured using a commercially available thiol detection kit. Compared with the thiol concentration in untreated bacteria, clusters $\mathbf{4 b}$ and $\mathbf{3}$ resulted in $\sim 50 \%$ reduction, similar to $\mathrm{Au}^{\mathrm{I}}$-complex 8. The smaller cluster 7 led to higher thiol levels, resulting in a decrease of only $12 \%$ relative to the untreated control.

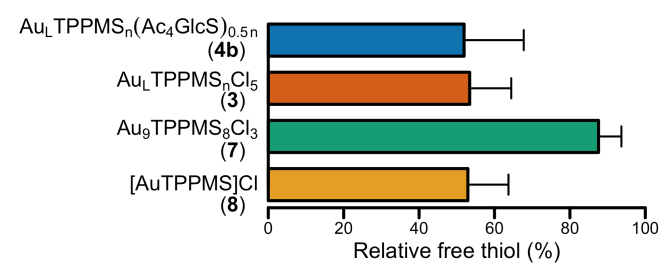

Figure 6: Free thiol concentration in PAO1 upon treating with different Au compounds $(9.8 \mu \mathrm{g} / \mathrm{mL}[\mathrm{Au}])$, with $100 \%$ being untreated bacteria.

\section{DISCUSSION}

All $\mathrm{Au}$ clusters and complexes tested were more active against Gram-positive bacteria compared to Gram-negative strains, mirroring the general trend observed with auranofin. The exchangeability of the TPPMS-protected $\mathrm{Au}_{\mathrm{L}} \mathrm{NC}$ enabled the preparation of auranofin AuNC analogues with varying levels of glycosylation. While the increase in glycosylation led to reduction in cytotoxicity, the antibacterial activity was less regular with the cluster $\mathrm{Au}_{\mathrm{L}}(\mathrm{TPPMS})_{\mathrm{n}}\left(\mathrm{Ac}_{4} \mathrm{GlcS}\right)_{2 \mathrm{n}}$ (4b) showing the best activity. Most notably, the MIC and MBC of cluster $\mathbf{4 b}$ against $P$. aeruginosa at $20 \mu \mathrm{g} / \mathrm{mL}[\mathrm{Au}]$ is an improvement over auranofin, which has an MIC of $74 \mu \mathrm{g} / \mathrm{mL}$ [Au] (Table 1). The water-soluble cluster 3 showed a similar activity as cluster $\mathbf{4 b}$, whereas the water-insoluble clusters $\mathbf{2}$ and $\mathbf{1}$ had no activity against Gram-negative bacteria. The reduced activity of the more hydrophobic AuNCs could be due to their lower availability in aqueous solution as is observed with other poorly water-soluble antibiotics. $^{41}$

The coordination of the $\mathrm{Ac}_{4} \mathrm{GlcSH}$ ligand to the AuNCs, formulating the auranofin analogue AuNCs, had a sizable impact on the antibacterial activity (Table $\underline{\mathbf{2}}$ ). An apparent 
optimal ligand ratio was obtained, where the highest activity against $P$. aeruginosa was observed at a $\mathrm{Ac}_{4} \mathrm{GlcS} / \mathrm{TPPMS}$ ratio of 1:2 (MIC $=20 \mu \mathrm{g} / \mathrm{mL}$ for cluster $\left.\mathbf{4 b}\right)$. The activity decreased drastically at higher $\mathrm{Ac}_{4} \mathrm{GlcS}$ content (MIC $>100 \mu \mathrm{g} / \mathrm{mL}$ for cluster 4d). The MICs of cluster $\mathbf{4 b}$ against the non-MDR $P$. aeruginosa strains PAO1 and ATCC 27853 were similar to the MDR strain NCTC 13437, which shows extensive resistance to $\beta$-lactams and aminoglycosides. ${ }^{83}$ This points toward a killing mechanism of the AuNCs that is different from these two traditional antibiotic classes. Interestingly, $\mathrm{Au}_{9}$ cluster 7 was less active than non-glycosylated AuNC 3 for all strains tested. The $\mathrm{Au}^{\mathrm{I}}$-complexes also showed liganddependent activity, where $\mathrm{Au}(\mathrm{TPPMS}) \mathrm{Cl}$ (8) had similar MICs as cluster 3, while $\mathrm{Au}(\mathrm{TPPMS})\left(\mathrm{Ac}_{4} \mathrm{GlcS}\right)(9)$ was more inert to the P. aeruginosa strains.

Glycosylation of cluster $\mathbf{3}$ also led to a slight reduction in cytotoxicity and cluster $\mathbf{4 b}$ displayed a higher $\mathrm{CC}_{50}$-value against $\mathrm{A} 549$ cells $(53 \pm 7.1 \mu \mathrm{g} / \mathrm{mL})$ compared to AuNC 3 (42 $\pm 12 \mu \mathrm{g} / \mathrm{mL}$, Table $\underline{3}$ ). This reduction in cellular toxicity has been postulated to result from a reduction in DNA-AuNC interactions due to the inability of DNA phosphate groups to replace thiols on the AuNCs. ${ }^{84}$ Our genotoxicity results indeed showed lower DSBs for the thiolated cluster $\mathbf{4 b}(18 \%)$ than for the non-thiolated cluster 3 (33\%, Figure $\underline{\mathbf{5}})$. In addition, the AuNCs were considerably less cytotoxic than auranofin, where cluster $\mathbf{4 b}$ displayed a 90 times higher SI compared to the Au complex (Table $\underline{6}$ ).

The first insight into the AuNC activity was provided by measuring the accumulation of $\mathrm{Au}$ in P. aeruginosa PAO1 using ICP-MS, showing that the uptake of $\mathrm{Au}$ from the larger $\mathrm{Au}_{\mathrm{L}}-$ clusters $(20 \%$ and $26 \%$ for $\mathbf{4 b}$ and $\mathbf{3})$ was considerably higher than from $\mathrm{Au}_{9}$-cluster $7(3.7 \%)$ and $\mathrm{Au}^{\mathrm{I}}$-complex $8(6.3 \%$, Figure $\mathbf{3})$. The uptake results of the clusters correlate well with their MIC values, with the higher Au uptake resulting in higher activity. Thus, $\mathrm{Au}_{\mathrm{L}}$-clusters $\mathbf{4 b}$ and 3 showed both a higher degree of uptake and better activity than the less incorporated $\mathrm{Au}_{9}$ cluster 7 . The stability test over $26 \mathrm{~h}$ pointed against the possibility that the uptake of the $\mathrm{Au}_{\mathrm{L}}-$ cluster could be the result of decomposition products into $\mathrm{Au}^{\mathrm{I}}$ or small AuNCs (Figure $\underline{\mathbf{3}}$ ). However, despite the relatively low uptake, the activity of complex $\mathbf{8}$ was similar to the AuNC clusters, implying that this complex requires lower accumulation to achieve similar killing.

Auranofin is inactive towards $P$. aeruginosa. One hypothesis to account for this is the OM barrier, supported by the observation that the activity of auranofin improved 1000-fold in the presence of a cationic peptide, polymyxin $\mathrm{B}^{27}$ For the $\mathrm{Au}^{\mathrm{I}}$ complex $\mathrm{Au}(\mathrm{TPPMS}) \mathrm{Cl}$, the addition of colistin led to a drastic 64-fold improvement in MIC. However, only a 4-fold enhancement was observed for the smaller $\mathrm{Au}_{9}$-cluster 7, and no change was observed for clusters $\mathbf{4 b}$ and $\mathbf{3}$. These results imply that $\mathrm{Au}^{\mathrm{I}}$ complex $\mathbf{8}$ has a relatively high intracellular activity but is limited by the inability to traverse the outer membrane. Another factor that contributes to the decrease in the activity of the $\mathrm{Au}^{\mathrm{I}}$ complex appears to be the interaction with extracellular proteins in the growth medium. Similar to auranofin, the activity of $\mathrm{Au}^{\mathrm{I}}$ complex 8 was reduced 4-fold in nutrient-rich broth versus in the minimal medium (Table 4 ). In comparison, AuNCs $\mathbf{3}$ and $\mathbf{4 b}$ were largely unaffected by the extracellular proteins in the growth medium. This behavior, together with the colistin co-administration data, explains the conflicting results of low accumulation yet moderate activity observed for the $\mathrm{Au}^{\mathrm{I}}$ complex. In contrast, while the AuNCs may not be as intracellularly active as the $\mathrm{Au}^{\mathrm{I}}$-complexes, their ability to effectively penetrate the bacterial cell wall results in similar activity. Internalization of AuNCs $(\sim 1-2 \mathrm{~nm})$ by bacteria has been reported in antibacterial and photosensitizing studies. ${ }^{82,85}$ However, the actual pathways that allow higher accumulation of larger clusters compared to the smaller $\mathrm{Au}_{9}$-clusters and $\mathrm{Au}^{\mathrm{I}}$-complexes warrant further investigations.

Assessment of DNA damage that leads to DSBs can determine whether DNA is the site of 
drug action or collateral damage of ROS species generated by AuNCs. From the analysis, it was evident that the Au compounds caused DNA damage compared to the negative controls of bacteria only and colistin. However, the degree of DSBs was considerably lower than ciprofloxacin, and more similar to that induced by $\mathrm{H}_{2} \mathrm{O}_{2}$ (Figure 5). This suggests that the $\mathrm{Au}$ compounds are less likely to interfere with bacterial DNA directly, and potentially more prone to cause damage through ROS generation. Of the clusters, $A_{\mathrm{L}}(\mathrm{TPPMS})_{\mathrm{n}}(3)$ displayed a higher level of DSBs compared to all other clusters, suggesting that some DNA-interaction could potentially occur. This hypothesis has been proposed for a TPPMS-protected "Au55" cluster of comparable size where the phosphine ligands were replaced with DNA phosphate groups, thereby allowing the AuNC core to insert into the major groove of DNA. ${ }^{67,84}$ This is further supported by lower levels of DSBs by the glycosylated cluster $\mathbf{4 b}$ where the $\mathrm{Ac}_{4} \mathrm{GlcS}-$ groups are significantly less likely to undergo exchange by phosphates. The smaller AuNC 7 and $\mathrm{Au}^{\mathrm{I}}$ complex $\mathbf{8}$ both induced intermediate levels of DSBs, most likely ROS-mediated in these cases.

Bacteria possess several mechanisms to respond to oxidative stress, including the thioredoxin and glutaredoxin systems that can mitigate the effects of ROS. The larger AuNCs $\mathbf{4 b}$ and $\mathbf{3}$ are only moderate inhibitors of TrxR, a key component of the Trx system, more than 500 times less active than auranofin (Table 6). The results indicate that inhibition of the thioredoxin system may not be the major antimicrobial mechanism for these AuNCs. We also quantified the amount of free thiols in bacteria exposed to Au clusters and complexes. Such thiols, like glutathione, are used by the GR/Grx system in Gram-negative bacteria to regulate oxidative stress. The thiol depletion assay showed that all Au clusters and complexes except $\mathrm{Au}_{9}$-cluster 7 reduced the intracellular thiols by $\sim 50 \%$ (Figure 6), indicating that, aside from Trx, thiol-dependent redox systems were compromised in the presence of AuNCs.

Considering the similarity in thiol depletion level and the difference in TrxR inhibition, the $\mathrm{AuNCs}$ and $\mathrm{Au}^{\mathrm{I}}$ complexes appear to affect the bacterial homeostasis by different mechanisms. For $\mathrm{Au}^{\mathrm{I}}$-complexes, like compound $\mathbf{8}$ and auranofin, the main source of disruption appears to be the strong inhibition of the TrxR/Trx system. Conversely, AuNCs $\mathbf{4 b}$ and 3 displayed low inhibition of TrxR and a higher effect on the GR/Grx system, possibly by direct reaction with GSH and other reduced thiols. This mechanism is supported by the inability of $\mathrm{Au}_{9}$-cluster 7 to reduce free thiols. Experimentally, the exchange of phosphine ligands by $\mathrm{Ac}_{4} \mathrm{GlcSH}$ was not feasible for this cluster, implying that it is less reactive to free thiols in bacteria. However, this does not exclude the possibility of intracellular AuNC degradation to generate active $\mathrm{Au}^{\mathrm{I}}$ species. Overall, these mechanisms point to the effectiveness of AuNCs $\mathbf{4 b}$ and $\mathbf{3}$ in limiting bacteria adaptability to oxidative stress that results in bactericidal activity.

\section{CONCLUSIONS}

Based on the structural motif of the FDA-approved gold drug auranofin, we designed AuNCs functionalized with mixed phosphine and glycosyl thiol ligands, synthesized by ligand exchange of $\mathrm{PPh}_{3}$-capped AuNCs with TPPMS followed by $\mathrm{Ac}_{4} \mathrm{GlcSH}$. The exchangeability of the TPPMS-protected AuLNCs enabled the preparation of clusters with increasing levels of glycosylation that were evaluated for their antibacterial activity and cytotoxicity. A collection of water-soluble $1.5 \mathrm{~nm} \mathrm{AuNCs}$ and $\mathrm{Au}_{9}$-clusters were thus prepared, of which the larger $\mathrm{Au}_{\mathrm{L}} \mathrm{NCs}$ demonstrated broad-spectrum activity against a range of bacteria, including highly resistant ESKAPE pathogens. In addition, the clusters displayed notably lower toxicity against human cells compared to auranofin. While the increase in glycosylation led to a 
proportional but gradual reduction in cytotoxicity, the antibacterial activity was less regular. Cluster $\mathbf{4 b}$ showed the highest activity and was less cytotoxic compared to the nonglycosylated counterpart 3 .

Investigations on the MOAs of the Au clusters and complexes against P. aeruginosa PAO1 revealed important aspects of the complex antibacterial mechanism of these entities with respect to the uptake, DNA damage, and disruption of redox homeostasis. Overall, the results show that the conversion of $\mathrm{Au}^{\mathrm{I}}$ complexes into an $\mathrm{AuNC}$ formulation can enhance the activity against bacteria and reduce toxicity towards human cells. The source of this enhancement combines several factors, including the ability of AuNCs to accumulate more effectively in bacteria than the $\mathrm{Au}^{\mathrm{I}}$ complexes, to translocate over the $\mathrm{OM}$ barrier, and to avoid extracellular protein interactions. The observed antibacterial mechanisms, including DNA damage, ROS generation, and inhibition of bacterial oxidative stress response, appeared multifaceted, showing both similarities and discrepancies compared to the MOAs observed for $\mathrm{Au}^{\mathrm{I}}$ complexes including auranofin.

The results from this study demonstrate that drug repurposing can be extended to nanoformulation. The retention of these properties opens up the possibility of this strategy as a formulation route in the drug development process, applied to enhance the efficacy of small coordination complexes as drugs in antimicrobial therapy.

\section{MATERIALS AND METHODS}

\section{Materials}

All reagents, solvents, and other chemicals were obtained in the highest available purity from commercial suppliers and generally used as received. Chloroform was passed through basic alumina before use. Deionized water was obtained from a Milli-Q ultrapure water purification system. All reactions were monitored by thin layer chromatography (TLC) using plates precoated with silica gel $60 \mathrm{~F}_{254}$ (Merck KGaA, Darmstadt, Germany), visualized under a hand-held ultraviolet light device or by staining with a $5 \% \mathrm{H}_{2} \mathrm{SO}_{4}$ solution in ethanol. Sephadex LH-20 (GE Lifesciences) was purchased from VWR (Radnor, PA, USA). TraceCERT $\mathrm{HCl}, \mathrm{HNO}_{3}$, and $\mathrm{Au}$ standard for ICP-MS analyses were from MilliporeSigma (St. Louis, MO, USA). ICP-MS measurements were performed on an Agilent 7900 ICP-MS. RecN-YFP images were collected using a Leica SP8 TCS laser scanning confocal microscope. E. coli Trx, E. coli TrxR and NADPH as well as the Thiol Detection Assay Kit were obtained from Cayman Chemical (Ann Arbor, MI).

ESI-MS spectra and TEM images were acquired using Bruker MicrOTOF II and JEOL JEM-2200FS instruments, respectively, at the University of Massachusetts Amherst. OD and fluorescence data were obtained using a Tecan Infinite PRO microplate reader and a Tecan Spark 10M plate reader. NMR spectra were recorded on Bruker Avance Spectrospin DRX500 $\left({ }^{1} \mathrm{H}\right.$ NMR) or JEOL ECZ $400 \mathrm{MHz}\left({ }^{31} \mathrm{P}\right.$ NMR) spectrometers. ${ }^{1} \mathrm{H}$ NMR signals are referenced to either (residual) solvent peaks or TMS ( $\delta 0.00 \mathrm{ppm})$. For ${ }^{31} \mathrm{P} \mathrm{NMR}, 85 \% \mathrm{H}_{3} \mathrm{PO}_{4}(0.00 \mathrm{ppm})$ was used as external reference. UV-Vis spectra were obtained using a PerkinElmer Lambda 750 UV-Vis NIR spectrometer.

Bacteria were cultured in either BBL Mueller Hinton Broth (MHB) from Becton, Dickinson and Company (Sparks, MD, USA) or LB broth from MilliporeSigma (St. Louis, $\mathrm{MO}$, USA). Antimicrobial assays were conducted in MHB, cation-adjusted with $\mathrm{Mg}^{2+}$ and $\mathrm{Ca}^{2+}$. BD Difco Dehydrated Culture Media: M9 Minimal Salts, 5x media was bought from Fisher Scientific (Hampton, NH, USA). P. aeruginosa ATCC 27853 and E. coli ATCC 25922 were purchased from ATCC (Manassas, VA, USA). Methicillin-resistant $S$. aureus USA300 
JE2 was from BEI resources (Manassas, VA, USA). E. coli SX1220 was purchased from The Coli Genetic Stock Center (CGSC \#12775) at Yale University (New Haven, CT, USA). A549 cells (ATCC CCL-185) and NIH/3T3 cells (ATCC CRL-1658) were purchased from ATCC. Dulbecco's Modified Eagle's Medium (DMEM) was acquired from MilliporeSigma. Ironfortified Bovine Calf Serum (SAFC Biosciences) and 0.25\% trypsin with EDTA (Gibco) were purchased from Fisher Scientific (Hampton, NH, USA). Cells were counted using a Countess automated hemocytometer from Invitrogen (Carlsbad, CA, USA).

\section{AuNC syntheses}

$\mathbf{A u}_{101}\left(\mathbf{P P h}_{3}\right)_{21} \mathbf{C l}_{5}$ (1). A modified method of Hutchison and coworkers was adopted. ${ }^{48}$ To a biphasic solution (toluene/water 1.3/1, v/v, $115 \mathrm{~mL}$ ) purged with Ar for $1 \mathrm{~h}$, TOAB (1.6 g, $2.9 \mathrm{mmol})$ and $\mathrm{HAuCl}_{4} \cdot 3 \mathrm{H}_{2} \mathrm{O}(1.0 \mathrm{~g}, 2.5 \mathrm{mmol})$ were added. The mixture was stirred for $10 \mathrm{~min}$, after which the yellow color in the aqueous layer disappeared and the organic layer turned red. Triphenylphosphine $(2.3 \mathrm{~g}, 8.9 \mathrm{mmol})$ was then added, and the reaction was stirred for a further $10 \mathrm{~min}$ until the organic phase was white and cloudy. A solution of $\mathrm{NaBH}_{4}$ $(1.4 \mathrm{~g}, 37 \mathrm{mmol})$ in water $(10 \mathrm{~mL})$ was immediately added, whereupon the mixture turned black. The reaction mixture was stirred under argon for $4 \mathrm{~h}$, after which the reaction mixture was washed with water $(3 \times 50 \mathrm{~mL})$. The organic layer was separated, and the solvent was evaporated to yield the crude product as a black solid. The crude was dispersed in hexanes by sonication and then filtered through a medium-porosity frit. The solid was then washed successively with: 1) hexanes $(200 \mathrm{~mL})$ followed by water $(100 \mathrm{~mL}), 2)$ hexanes $(5 \times 100 \mathrm{~mL})$ followed by $\mathrm{MeOH} /$ water $2: 3$, v/v $(100 \mathrm{~mL}), 3)$ hexanes $(5 \times 100 \mathrm{~mL})$ followed by saturated sodium nitrite solution $(100 \mathrm{~mL}), 4)$ hexanes $(5 \times 100 \mathrm{~mL})$ followed by $\mathrm{MeOH} /$ water 2:3, v/v $(100 \mathrm{~mL}), 5)$ hexanes $(5 \times 100 \mathrm{~mL})$ followed by saturated sodium nitrite solution $(100 \mathrm{~mL})$, and 6) hexanes $(5 \times 50 \mathrm{~mL})$ followed by $\mathrm{MeOH} /$ water $2: 3, \mathrm{v} / \mathrm{v}$ $(100 \mathrm{~mL})$. The washed product was dissolved in chloroform, concentrated $(\sim 10 \mathrm{~mL})$, and slowly precipitated with pentane dispensed from a syringe pump at $10 \mathrm{~mL} / \mathrm{h}$ over $2 \mathrm{~h}$. This process was repeated 3 times, after which the solvent was evaporated to give cluster $\mathbf{1}$ as a black solid (190 mg, 27\% [Au]). ${ }^{1} \mathrm{H} \mathrm{NMR}\left(\mathrm{CDCl}_{3}, 400 \mathrm{MHz}\right): \delta 7.2$ (br)

$\mathbf{A u}_{\mathbf{L}}\left(\mathbf{P P h}_{\mathbf{3}}\right)_{\mathbf{x}}\left(\mathbf{A c}_{\mathbf{4}} \mathbf{G l c S}\right)_{\mathbf{y}} \mathbf{( 2 )}$. Cluster $\mathbf{1}(10 \mathrm{mg}, 0.39 \mathrm{mmol})$ and $\mathrm{Ac}_{4} \mathrm{GlcSH}(2.3 \mathrm{mg}$, $6.4 \mathrm{mmol})$ were dissolved in DCM $(5.0 \mathrm{~mL})$ and the reaction was stirred at room temperature for $12 \mathrm{~h}$. The reaction mixture was concentrated and purified by size exclusion chromatography $(\mathrm{DCM} / \mathrm{MeOH} 1: 5, \mathrm{v} / \mathrm{v})$, after which the free ligand $\left(\mathrm{R}_{\mathrm{f}}: 0.4\right.$, hexanes/EtOAc $1: 1, \mathrm{v} / \mathrm{v})$ disappeared as visualized by TLC. The solvent was evaporated to give cluster 2 as a black solid (4.0 mg, 40\% [Au]). ${ }^{1} \mathrm{H}$ NMR $\left(\mathrm{CDCl}_{3}, 400 \mathrm{MHz}\right): \delta 7.2(\mathrm{br}), 2.1$ (br). ${ }^{31} \mathrm{P}$ NMR $\left(\mathrm{CDCl}_{3}, 162 \mathrm{MHz}\right)$ : Not discernible.

$\mathbf{A u}_{\mathbf{L}}$ (TPPMS) (3). Cluster $\mathbf{1}(10 \mathrm{mg}, 0.39 \mathrm{mmol})$ was dissolved in DCM (3 mL), to which a solution of TPPMS (7.1 mg, $2.0 \mathrm{mmol})$ in water $(3.0 \mathrm{~mL})$ was added, and the biphasic mixture stirred at room temperature for $12 \mathrm{~h}$. Following separation of the solvent phases, the aqueous layer was washed with $\operatorname{DCM}(3 \times 10 \mathrm{~mL})$ and the organic layer with water $(3 \times 10 \mathrm{~mL})$, after which the combined aqueous phase was concentrated. Purification by size exclusion chromatography (MeOH/water 4:1, v/v) yielded product 3 as a black solid $(7.9 \mathrm{mg}$, $70 \%[\mathrm{Au}]) .{ }^{1} \mathrm{H}$ NMR $\left(\mathrm{D}_{2} \mathrm{O}, 400 \mathrm{MHz}\right): \delta 7.3$ (br). ${ }^{31} \mathrm{P} \mathrm{NMR}\left(\mathrm{CDCl}_{3}, 162 \mathrm{MHz}\right)$ : Not discernible.

$\mathbf{A u}_{\mathbf{L}}(\mathbf{T P P M S})_{\mathbf{x}}\left(\mathbf{A c}_{\mathbf{4}} \mathbf{G l c}\right)_{\mathbf{y}}(\mathbf{4 a}-\mathbf{4 d})$. Cluster $3(12 \mathrm{mg})$ was dissolved in $\mathrm{MeOH}(4 \mathrm{~mL})$ and the solution was heated to $40{ }^{\circ} \mathrm{C}$. $\mathrm{Ac}_{4} \mathrm{GlcSH}$, in a mole ratio of $4,16,64$, or 256 to the cluster, was dissolved in DCM $(0.5 \mathrm{~mL})$ and added to the stirring solution. The reactions were performed at $40{ }^{\circ} \mathrm{C}$ for $12 \mathrm{~h}$. The resulting solutions were concentrated and purified by size 
exclusion chromatography $(\mathrm{MeOH} /$ water $4: 1, \mathrm{v} / \mathrm{v})$. Purity was confirmed by the absence of free ligand $\left(\mathrm{R}_{\mathrm{f}}: 0.4\right.$, hexanes/EtOAc $\left.1: 1, \mathrm{v} / \mathrm{v}\right)$ by TLC. After evaporation of the solvent to dryness, products 4a-4d were obtained as dark brown/black solids, $\mathbf{4 a}$ (7.7 mg, 64\% [Au]), $4 \mathbf{b}$ (8.0 mg, 66\% [Au]), 4c (8.5 mg, 70\% [Au]), 4d (9.3 mg, 76\%[Au]). ${ }^{1} \mathrm{H}$ NMR $\left(\mathrm{D}_{2} \mathrm{O}\right.$, $400 \mathrm{MHz}): \delta 7.3$ (br), 2.1 (br). ${ }^{31} \mathrm{P}$ NMR $\left(\mathrm{CDCl}_{3}, 162 \mathrm{MHz}\right)$ : Not discernible.

$\left[\mathbf{A u}_{11}\left(\mathbf{P P h}_{3}\right)_{\mathbf{8}} \mathbf{C l} \mathbf{l}_{\mathbf{2}}\right] \mathbf{C l}(\mathbf{5}){ }^{59,86}$ To a stirred solution of $\mathrm{Au}\left(\mathrm{PPh}_{3}\right) \mathrm{Cl}(0.66 \mathrm{~g}, 1.3 \mathrm{mmol})$ in DCM (28 mL), $\mathrm{NaBH}_{4}(14 \mathrm{mg}, 0.37 \mathrm{mmol})$ in absolute ethanol $(4.2 \mathrm{~mL})$ was quickly added, and the reaction allowed to proceed while stirring at room temperature for $24 \mathrm{~h}$. The crude product was purified by successive slow precipitation using pentanes, followed by column chromatography (DCM/MeOH 20:1, 15:1, 10:1, 5:1, v/v). Following concentration to dryness, product 5 was obtained as a red solid $(11 \mathrm{mg}, 40 \%[\mathrm{Au}]) .{ }^{1} \mathrm{H}$ NMR $\left(\mathrm{CDCl}_{3}\right.$, $400 \mathrm{MHz}$ ): $\delta 7.30(\mathrm{br}, 2 \mathrm{H}), 6.93(\mathrm{t}, 1 \mathrm{H}, J=7.4 \mathrm{~Hz}), 6.68(\mathrm{t}, 2 \mathrm{H}, J=7.6 \mathrm{~Hz}) .{ }^{31} \mathrm{P}$ NMR $\left(\mathrm{CDCl}_{3}, 162 \mathrm{MHz}\right): \delta 53.05$.

$\mathbf{A u}_{11}\left(\mathbf{P P h}_{3}\right)_{\mathbf{x}}\left(\mathbf{A c}_{\mathbf{4}} \mathbf{G l c}\right)_{\mathbf{y}}(\mathbf{6})$. $\left[\mathrm{Au}_{11}\left(\mathrm{PPh}_{3}\right)_{8} \mathrm{Cl}_{2}\right] \mathrm{Cl}(\mathbf{5}, 4.9 \mathrm{mg}, 1.6 \mu \mathrm{mol})$ was dissolved in $\mathrm{DCM} / 1$-chlorobutane $3: 1, \mathrm{v} / \mathrm{v}(4.0 \mathrm{~mL})$ and heated to $50{ }^{\circ} \mathrm{C}$. To this solution, $\mathrm{Ac}_{4} \mathrm{GlcSH}$ (4.5 mg, $12 \mu \mathrm{mol}$ ) was added while stirring, and the solution was heated for $4 \mathrm{~h}$ until the solution turned from red to brown. The solvent was removed, and the product was purified by size exclusion chromatography (ethanol), supported by the absence of free ligand $\left(\mathrm{R}_{\mathrm{f}}: 0.4\right.$, hexanes/EtOAc 1:1, v/v) by TLC. Following concentration to dryness, product $\mathbf{6}$ was obtained as a brown solid. (3.7 mg, 76\%). ${ }^{1} \mathrm{H} \mathrm{NMR}\left(\mathrm{CDCl}_{3}, 500 \mathrm{MHz}\right): \delta 7.6-7.3(\mathrm{~m}, 15 \mathrm{H}), 5.0-5.3(\mathrm{~m}$, $4 \mathrm{H}), 4.2-4.5(\mathrm{~m}, 2 \mathrm{H}), 2.0-2.2(\mathrm{~m}, 12 \mathrm{H}){ }^{31} \mathrm{P} \mathrm{NMR}\left(\mathrm{CDCl}_{3}, 81 \mathrm{MHz}\right)$ : NMR $(\delta 44.23)$

[Au $\mathbf{A u}_{\mathbf{9}}$ (TPPMS $\left.)_{\mathbf{8}} \mathbf{C C l}_{3}(\mathbf{7}) . \mathrm{Au}_{11}\left(\mathrm{PPh}_{3}\right)_{8} \mathrm{Cl}_{2}\right] \mathrm{Cl}(\mathbf{5}, 11 \mathrm{mg}, 2.5 \mu \mathrm{mol})$ was dissolved in DCM $(3.0 \mathrm{~mL})$ and the solution was added to TPPMS $(18 \mathrm{mg}, 50 \mu \mathrm{mol})$ dissolved in water $(3 \mathrm{~mL})$, after which the resulting biphasic mixture was stirred vigorously while heating at $40{ }^{\circ} \mathrm{C}$. After $4 \mathrm{~h}$, the red color had completely transferred to the aqueous layer. Following separation of the solvent phases, the aqueous layer was washed with DCM $(3 \times 5 \mathrm{~mL})$ and the organic layer with water $(3 \times 5 \mathrm{~mL})$, after which the combined aqueous phase was concentrated. Following purification by size exclusion chromatography $(\mathrm{MeOH} /$ water $=4: 1 \mathrm{v} / \mathrm{v})$, the colored fractions were lyophilized, yielding product 7 as a powdery red solid. (13.3 mg, 91\% [Au]). ${ }^{1} \mathrm{H}$ NMR $\left(\mathrm{D}_{2} \mathrm{O}, 400 \mathrm{MHz}\right): \delta 7.36(\mathrm{~d}, 1 \mathrm{H}, J=7.9 \mathrm{~Hz}), 7.24(\mathrm{~s}, 1 \mathrm{H}), 7.05(\mathrm{~m}, 8 \mathrm{H}), 6.71(\mathrm{t}, 4 \mathrm{H}$, $J=7.7 \mathrm{~Hz}), 6.36(\mathrm{t}, 1 \mathrm{H}, J=7.8 \mathrm{~Hz}) .{ }^{31} \mathrm{P} \mathrm{NMR}\left(\mathrm{D}_{2} \mathrm{O}, 162 \mathrm{MHz}\right): \delta 57.81$.

\section{Determination of MIC and MBC}

MICs and MBCs were determined by the broth microdilution method, as described in the Clinical \& Laboratory Standards Institute (CLSI) guidelines. ${ }^{87}$ The compounds were dissolved in either DMSO or water as stock solutions. All bacterial strains were cultured in CAMHB up to log phase and then diluted to match $0.5 \times$ McFarland standard using $0.85 \%$ saline. This bacterial suspension was diluted to $\sim 1 \times 10^{6} \mathrm{CFU} / \mathrm{mL}$ and then dispensed in aliquots $(100 \mu \mathrm{L})$ to a 96 -well plate containing volumes $(100 \mu \mathrm{L})$ of two-fold serially diluted compound solutions. After incubation at $35{ }^{\circ} \mathrm{C}$ for $18 \mathrm{~h}$, the plates were checked spectrophotometrically for growth $\left(\mathrm{OD}_{600}\right)$ and/or by incubation with $10 \%$ alamarBlue for $2 \mathrm{~h}$ followed by fluorimetry. The MIC was the concentration that resulted in an absorbance less than $90 \%$ of the control at $600 \mathrm{~nm}\left(\mathrm{OD}_{600}\right)$, showing $90 \%$ less absorbance $(570 \mathrm{~nm})$ or fluorescence (Ex: $570 \mathrm{~nm}, \mathrm{Em}: 590 \mathrm{~nm}$ ) in the case of alamarBlue. To determine the MBCs, agar plates were treated with sample solutions $(5 \mu \mathrm{L})$ from each well and then incubated at $35{ }^{\circ} \mathrm{C}$ for $18 \mathrm{~h}$ without shaking. The sample concentrations that resulted in no colony formation on agar plates were the MBCs.

MIC determination in minimal medium followed the same protocol as above except that 
M9 Minimal Salts (BD Difco) medium was used. The medium was prepared following the manufacturer's instructions and supplemented with $1 \mathrm{mM} \mathrm{MgSO}, 0.5 \mathrm{mM} \mathrm{CaCl}_{2}$, and $0.4 \%$ D-glucose as the carbon source. Bacteria was grown in M9 medium until an OD of $\sim 0.3$ and then diluted to match $0.5 \times \mathrm{McF}$ arland standard using $0.85 \%$ saline.

\section{Determination of $\mathrm{CC}_{50}$ for $\mathrm{A549}$ cells}

A549 cells were cultured in DMEM supplemented with 10\% fetal bovine serum and 1\% each of penicillin/streptomycin, gentamicin sulfate, and amphotericin B. Cells were grown to $80-90 \%$ confluency in a humidified chamber kept at $37{ }^{\circ} \mathrm{C}$ and $5 \% \mathrm{CO}_{2}$. The confluent cells were detached from the flasks and seeded in a 96-well plate overnight at a concentration of 5,000 cells per well. The medium was removed, and aliquots $(80 \mu \mathrm{L})$ containing compounds were added to the wells. The cells were incubated with the compounds for $18 \mathrm{~h}$, after which the medium was removed and $10 \%$ of alamarBlue solution $(100 \mu \mathrm{L})$ in DMEM complete culture media was added to the wells. The well plates were incubated for a further $3 \mathrm{~h}$ before fluorescence readings were obtained using a Tecan Infinite PRO 200 plate reader (Ex: $575 \mathrm{~nm}, \mathrm{Em}: 590 \mathrm{~nm}$ ). The $\mathrm{CC}_{50}$ values were determined by analyzing the fluorescence intensity vs. $\log [\mathrm{Au}]$ by standard nonlinear regression (Origin PRO/Graphpad Prism). Complete sigmoidal curves were observed for the compounds (Figures S5-S6)].

\section{Determination of Au uptake by $P$. aeruginosa}

P. aeruginosa PAO1 was cultured to log phase and then adjusted to $4.2 \times 0.5 \mathrm{McFarland}$ standard as determined by $\mathrm{OD}_{600}$. Volumes of this bacterial suspension $(0.95 \mathrm{~mL})$ were combined with solutions of the gold compounds ( $50 \mu \mathrm{L}$, final concentration $8 \mu \mathrm{g} / \mathrm{mL})$ and were incubated at $35{ }^{\circ} \mathrm{C}$ for $4 \mathrm{~h}$ without shaking. The cultures were pelleted $(3000 \times g$ for 6 min) and washed with PBS $(3 \times 1 \mathrm{~mL})$. The samples were then digested at room temperature overnight using freshly prepared aqua regia $(1.0 \mathrm{~mL})\left(\mathrm{HCl} / \mathrm{HNO}_{3}=4: 1 \mathrm{v} / \mathrm{v}\right.$, using TraceCERT acids), followed by heating to $60{ }^{\circ} \mathrm{C}$ for $2 \mathrm{~h}$ at which point no solids were visible in the solution. The samples were diluted in $2 \% \mathrm{HNO}_{3}$ and analyzed by ICP-MS against a standard series prepared from a TraceCERT Au Standard for ICP. The accumulated Au content was quantified as the percentage of the total $\mathrm{Au}$ in the initially added gold compounds. For each experiment, the final bacteria count was established by dilution and plating followed by incubation for $18 \mathrm{~h}$. The final concentration of Au was then normalized to the bacteria counts using $4.0 \times 10^{9} \mathrm{CFU} / \mathrm{mL}$ as the baseline.

\section{Genotoxicity assay}

E. coli $\mathrm{SX} 1220$, cultured to a density equal to $0.5 \mathrm{McF}$ arland standard, were incubated with gold compounds at a sub-MIC level $(8 \mu \mathrm{g} / \mathrm{ml})$ for $1 \mathrm{~h}$. The bacteria were then pelleted (3000 $\times \mathrm{g}$ for $6 \mathrm{~min})$, washed once with PBS $(1.0 \mathrm{~mL})$, and then fixed using $4 \%$ paraformaldehyde $(1.0 \mathrm{~mL})$ at room temperature for $15 \mathrm{~min}$. The pellets were washed with PBS $(3 \times 1.0 \mathrm{~mL})$ to remove the excess aldehyde and redispersed in PBS $(1.0 \mathrm{~mL})$. The samples $(2.5 \mu \mathrm{L})$ were mounted on cleaned slides using ProLong Glass Antifade Mountant with NucBlue Stain (5.0 $\mu \mathrm{L}$ ), covered using cleaned \#1.5H glass slips. After being left to cure for at least $24 \mathrm{~h}$, confocal images were acquired using the $405 \mathrm{~nm}$ excitation laser line for DAPI and the $488 \mathrm{~nm}$ laser line for YFP. The images obtained were processed and analyzed using the Leica Application Suite X (LAS X) software. 


\section{Determination of $\mathrm{IC}_{50}$ for $\operatorname{TrxR}$}

All solutions were prepared in $50 \mathrm{mM}$ HEPES buffer, $\mathrm{pH} 7.5$, with $1 \mathrm{mM}$ EDTA, and the experiments were conducted using black, clear-bottom 96-well plates. A $250 \mathrm{nM}$ solution of TrxR $(10 \mu \mathrm{L})$ was combined with $0.067 \mathrm{mM}$ NADPH $(15 \mu \mathrm{L})$ and $0.0 .067 \mathrm{mM}$ of DTNB solution $(15 \mu \mathrm{L})$. Aliquots $(50 \mu \mathrm{L})$ of serially diluted solutions of Au compounds were then added to the wells and the mixtures were incubated at $30^{\circ} \mathrm{C}$ for $10 \mathrm{~min}$. The reaction was initiated by the addition of the Trx solution $(100 \mu \mathrm{M}, 10 \mu \mathrm{L})$, and the absorbance of the reduced DTNB was recorded at $412 \mathrm{~nm}$ every minute for $10 \mathrm{~min} .{ }^{9}$ The enzyme activity in the presence of the gold compound compared to the reference without inhibitor $\left(\triangle A b s_{\text {AuNC }} / \Delta A b s_{\text {ref }}\right)$ vs. $\log [\mathrm{Au}]$ was used to estimate half-maximal inhibitory concentration $\mathrm{IC}_{50}$ using standard non-linear regression analysis (Origin PRO/Graphpad Prism). Two independent assays were performed and the final $\mathrm{IC}_{50}$ values were averaged.

\section{Quantification of free thiols}

P. aeruginosa PAO1 was obtained from a single colony and grown overnight in CAMHB to OD600 1.0. The culture was diluted to OD600 0.5 and incubated with $50 \mu \mathrm{M}$ of $\mathrm{Au}$ compound for $5 \mathrm{~h}$. The cultures were then pelleted $(7,000 \times g$ for 5 minutes), washed twice with PBS $(1.0 \mathrm{~mL})$, and then resuspended in PBS $(3 \mathrm{~mL})$. The bacteria were lysed via probe sonication using Vibra-Cell VCX 130 (Sonics) with a pulse of $9 \mathrm{~s}$ on and $9 \mathrm{~s}$ off at $30 \%$ amplitude for $5 \mathrm{~min}$. Thiols were detected and quantified using the Thiol Detection Assay Kit (Cayman Chemicals) at an excitation wavelength of $365 \mathrm{~nm}$ and an emission wavelength of $520 \mathrm{~nm}$.

\section{AUTHOR INFORMATION}

\section{Corresponding authors}

Mingdi Yan; E-mail: Mingdi_Yan@uml.edu

Olof Ramström; E-mail: olof_ramstrom@uml.edu

\section{ACKNOWLEDGEMENTS}

This study was in part supported by the National Institutes of Health (AI140418). The following reagent was provided by the Network on Antimicrobial Resistance in Staphylococcus aureus (NARSA) for distribution by BEI Resources, NIAID, NIH: S. aureus ssp. aureus, Strain JE2, NR-46543.

\section{KEYWORDS}

Gold nanoclusters, auranofin, antimicrobial, Pseudomonas aeruginosa, glyconanoparticles

\section{REFERENCES}

(1) U.S. Department of Health and Human Services; CDC. Antibiotic resistance threats in the United States; 2019.

(2) Pushpakom, S.; Iorio, F.; Eyers, P. A.; Escott, K. J.; Hopper, S.; Wells, A.; Doig, A.; Guilliams, T.; Latimer, J.; McNamee, C.; Norris, A.; Sanseau, P.; Cavalla, D.; Pirmohamed, M. Nat. Rev. Drug Discov. 2019, 18 (1), 41-58. 
(3) Brown, D. Nat. Rev. Drug Discov. 2015, 14 (12), 821-832.

(4) Abutaleb, N. S.; Seleem, M. N. Sci. Rep. 2020, 10 (1).

(5) Roder, C.; Athan, E. Drugs R D 2020, 20 (3), 209-216.

(6) AbdelKhalek, A.; Abutaleb, N. S.; Elmagarmid, K. A.; Seleem, M. N. Sci. Rep. 2018, 8 (1), 1-9.

(7) Thangamani, S.; Mohammad, H.; Abushahba, M. F. N.; Sobreira, T. J. P.; Seleem, M. N. Int. J. Antimicrob. Agents 2016, 47 (3), 195-201.

(8) Owings, J. P.; McNair, N. N.; Mui, Y. F.; Gustafsson, T. N.; Holmgren, A.; Contel, M.; Goldberg, J. B.; Mead, J. R. FEMS Microbiol. Lett. 2016, 363 (14), fnw148.

(9) Harbut, M. B.; Vilchèze, C.; Luo, X.; Hensler, M. E.; Guo, H.; Yang, B.; Chatterjee, A. K.; Nizet, V.; Jacobs, W. R.; Schultz, P. G.; Wang, F. Proc. Natl. Acad. Sci. USA 2015, 112 (14), 4453-4458.

(10) Hokai, Y.; Jurkowicz, B.; Fernández-Gallardo, J.; Zakirkhodjaev, N.; Sanaú, M.; Muth, T. R.; Contel, M. J. Inorg. Biochem. 2014, 138, 81-88.

(11) Jackson-Rosario, S.; Cowart, D.; Myers, A.; Tarrien, R.; Levine, R. L.; Scott, R. A.; Self, W. T. J. Biol. Inorg. Chem. 2009, 14 (4), 507-519.

(12) Rossi, S. A.; Oliveira, H. C. de; Agreda-Mellon, D.; Lucio, J.; Mendes-Giannini, M. J. S.; García-Cambero, J. P.; Zaragoza, O. Antimicrob. Agents Chemother. 2020, 64 (4).

(13) Wiederhold, N. P.; Patterson, T. F.; Srinivasan, A.; Chaturvedi, A. K.; Fothergill, A. W.; Wormley, F. L.; Ramasubramanian, A. K.; Lopez-Ribot, J. L. Virulence 2017, 8 (2), 138-142.

(14) Thangamani, S.; Maland, M.; Mohammad, H.; Pascuzzi, P. E.; Avramova, L.; Koehler, C. M.; Hazbun, T. R.; Seleem, M. N. Front. Cell. Infect. Microbiol. 2017, 7, 4.

(15) May, H. C.; Yu, J.-J.; Guentzel, M. N.; Chambers, J. P.; Cap, A. P.; Arulanandam, B. P. Front. Microbiol. 2018, 9, 336.

(16) Sannella, A. R.; Casini, A.; Gabbiani, C.; Messori, L.; Bilia, A. R.; Vincieri, F. F.; Majori, G.; Severini, C. FEBS Lett. 2008, 582 (6), 844-847.

(17) Gil-Moles, M.; Basu, U.; Büssing, R.; Hoffmeister, H.; Türck, S.; Varchmin, A.; Ott, I. Chem. Eur. J. 2020 , 26 (66), 15140-15144.

(18) Rothan, H. A.; Stone, S.; Natekar, J.; Kumari, P.; Arora, K.; Kumar, M. Virology 2020.

(19) Stratton, M.; Ramachandran, A.; Camacho, E. J. M.; Patil, S.; Waris, G.; Grice, K. A. J. Inorg. Biochem. 2020, 206, 111023.

(20) Lewis, M. G.; DaFonseca, S.; Chomont, N.; Palamara, A. T.; Tardugno, M.; Mai, A.; Collins, M.; Wagner, W. L.; Yalley-Ogunro, J.; Greenhouse, J. AIDS 2011, 25 (11), 1347-1356.

(21) Fonteh, P. N.; Keter, F. K.; Meyer, D. Biometals 2010, 23 (2), 185-196.

(22) Marzano, C.; Gandin, V.; Folda, A.; Scutari, G.; Bindoli, A.; Rigobello, M. P. Free Radic. Biol. Med. 2007, 42 (6), 872-881.

(23) Talbot, S.; Nelson, R.; Self, W. T. Br. J. Pharmacol. 2008, 154 (5), 940-948.

(24) Gromer, S.; Johansson, L.; Bauer, H.; Arscott, L. D.; Rauch, S.; Ballou, D. P.; Williams, C. H.; Schirmer, R. H.; Arner, E. S. J. Proc. Natl. Acad. Sci. USA 2003, 100 (22), 12618-12623.

(25) Saccoccia, F.; Angelucci, F.; Boumis, G.; Carotti, D.; Desiato, G.; Miele, A.; Bellelli, A. Curr Protein Pept Sc 2014, 15 (6), 621-646.

(26) Holmgren, A. J. Biol. Chem. 1989, 264 (24), 13963-13966.

(27) Thangamani, S.; Mohammad, H.; Abushahba, M. F. N.; Sobreira, T. J. P.; Hedrick, V. E.; Paul, L. N.; Seleem, M. N. Sci. Rep. 2016, 6, 22571-22571.

(28) Lu, J.; Vlamis-Gardikas, A.; Kandasamy, K.; Zhao, R.; Gustafsson, T. N.; Engstrand, L.; Hoffner, S.; Engman, L.; Holmgren, A. FASEB J. 2012, 27 (4), 1394-1403.

(29) Jin, R.; Zeng, C.; Zhou, M.; Chen, Y. Chem. Rev. 2016, 116 (18), 10346-10413.

(30) Yang, X.; Yang, M.; Pang, B.; Vara, M.; Xia, Y. Chem. Rev. 2015, 115 (19), 10410-10488.

(31) Liyanage, S. H.; Yan, M. Chem. Commun. 2020, 56 (88), 13491-13505.

(32) Zheng, Y.; Liu, W.; Chen, Y.; Li, C.; Jiang, H.; Wang, X. J. Colloid Interface Sci. 2019, 546, 1-10.

(33) Wang, S.; Wang, Y.; Peng, Y.; Yang, X. ACS Appl. Mater. Interfaces 2019, 11 (8), 8461-8469.

(34) Kalita, S.; Kandimalla, R.; Bhowal, A. C.; Kotoky, J.; Kundu, S. Sci Rep 2018, 8 (1), 5778. 
(35) Li, Q.; Pan, Y.; Chen, T.; Du, Y.; Ge, H.; Zhang, B.; Xie, J.; Yu, H.; Zhu, M. Nanoscale 2018, 10 (21), 10166-10172.

(36) Liang, J.; Xiong, H.; Wang, W.; Wen, W.; Zhang, X.; Wang, S. Sens. Actuators B Chem. 2018, 255, 2170-2178.

(37) Chen, W.-Y.; Chang, H.-Y.; Lu, J.-K.; Huang, Y.-C.; Harroun, S. G.; Tseng, Y.-T.; Li, Y.-J.; Huang, C.-C.; Chang, H.-T. Adv. Funct. Mater. 2015, 25 (46), 7189-7199.

(38) Li, Y.; Zhen, J.; Tian, Q.; Shen, C.; Zhang, L.; Yang, K.; Shang, L. J. Colloid Interface Sci. 2020, 569, 235-243.

(39) Ravindran Girija, A.; Balasubramanian, S.; Bright, R.; Cowin, A. J.; Goswami, N.; Vasilev, K. ChemNanoMat 2019, 5 (9), 1176-1181.

(40) Zheng, Y.; Liu, W.; Qin, Z.; Chen, Y.; Jiang, H.; Wang, X. Bioconjug. Chem. 2018, 29 (9), 3094-3103.

(41) Zheng, K.; Setyawati, M. I.; Leong, D. T.; Xie, J. ACS Nano 2017, 11 (7), 6904-6910.

(42) Yougbare, S.; Chang, T. K.; Tan, S. H.; Kuo, J. C.; Hsu, P. H.; Su, C. Y.; Kuo, T. R. Int. J. Mol. Sci. 2019, 20

(12), 2924.

(43) Glišić, B. Đ.; Djuran, M. I. Dalton Trans. 2014, 43 (16), 5950-5969.

(44) Shaw, C. F. Chem. Rev. 1999, 99 (9), 2589-2600.

(45) Boda, S. K.; Broda, J.; Schiefer, F.; Weber-Heynemann, J.; Hoss, M.; Simon, U.; Basu, B.; Jahnen-Dechent, W. Small 2015, 11 (26), 3183-3193.

(46) Li, M.-B.; Tian, S.-K.; Wu, Z.; Jin, R. Chem. Mater. 2016, 28 (4), 1022-1025.

(47) Schmid, G.; Alexander, B. D.; Barthelmes, J.; Mueting, A. M.; Pignolet, L. H. Inorg. Synth. 1990, 214-218.

(48) Weare, W. W.; Reed, S. M.; Warner, M. G.; Hutchison, J. E. J. Am. Chem. Soc. 2000, 122 (51), $12890-12891$.

(49) Brown, L. O.; Hutchison, J. E. J. Am. Chem. Soc. 1997, 119 (50), 12384-12385.

(50) Kenzler, S.; Fetzer, F.; Schrenk, C.; Pollard, N.; Frojd, A. R.; Clayborne, A. Z.; Schnepf, A. Angew. Chem. Int. Ed. 2019, 58 (18), 5902-5905.

(51) Konishi, K. In Structure and bonding; Springer International Publishing, 2014; pp 49-86.

(52) Wijenayaka, L. A.; Ivanov, M. R.; Cheatum, C. M.; Haes, A. J. J. Phys. Chem. C 2015, 119 (18), 10064-10075.

(53) Schulz, F.; Vossmeyer, T.; Bastús, N. G.; Weller, H. Langmuir 2013, 29 (31), 9897-9908.

(54) Petroski, J.; Chou, M. H.; Creutz, C. Inorg. Chem. 2004, 43 (5), 1597-1599.

(55) Sharma, R.; Holland, G. P.; Solomon, V. C.; Zimmermann, H.; Schiffenhaus, S.; Amin, S. A.; Buttry, D. A.; Yarger, J. L. J. Phys. Chem. C 2009, 113 (37), 16387-16393.

(56) Shu, P.; Zeng, J.; Tao, J.; Zhao, Y.; Yao, G.; Wan, Q. Green Chem. 2015, 17 (4), 2545-2551.

(57) Karschin, A.; Kläui, W.; Peters, W.; Spingler, B. Eur. J. Inorg. Chem. 2010, 2010 (6), 942-946.

(58) Snee, P. T. Acc. Chem. Res. 2018, 51 (11), 2949-2956.

(59) McKenzie, L. C.; Zaikova, T. O.; Hutchison, J. E. J. Am. Chem. Soc. 2014, 136 (38), 13426-13435.

(60) Woehrle, G. H.; Hutchison, J. E. Inorg. Chem. 2005, 44 (18), 6149-6158.

(61) Caragheorgheopol, A.; Chechik, V. Phys. Chem. Chem. Phys. 2008, 10 (33), 5029.

(62) Sanz, S.; Jones, L. A.; Mohr, F.; Laguna, M. Organometallics 2007, 26 (4), 952-957.

(63) Coffer, M. T.; Shaw, C. F.; Eidsness, M. K.; Watkins, J. W.; Elder, R. C. Inorg. Chem. 1986, 25 (3), 333-339.

(64) Krishnamoorthy, G.; Leus, I. V.; Weeks, J. W.; Wolloscheck, D.; Rybenkov, V. V.; Zgurskaya, H. I. mBio 2017, $8(5)$.

(65) Delcour, A. H. Biochim. Biophys. Acta Proteins Proteom. 2009, 1794 (5), 808-816.

(66) Schmid, G.; Kreyling, W. G.; Simon, U. Arch. Toxicol. 2017, 91 (9), 3011-3037.

(67) Tsoli, M.; Kuhn, H.; Brandau, W.; Esche, H.; Schmid, G. Small 2005, 1 (8-9), 841-844.

(68) Ahmed, M. A. E.-G. E.-S.; Zhong, L.-L.; Shen, C.; Yang, Y.; Doi, Y.; Tian, G.-B. Emerg. Microbes Infect. 2020, 9 (1), 868-885.

(69) Nation, R. L.; Li, J. Curr. Opin. Infect. Dis. 2009, 22 (6), 535-543. 
(70) Hooper, D. C. Drugs 1999, 58 Suppl 2, 6-10.

(71) Hong, Y.; Zeng, J.; Wang, X.; Drlica, K.; Zhao, X. Proc. Natl. Acad. Sci. USA 2019, 116 (20), 10064-10071.

(72) Hong, Y.; Li, L.; Luan, G.; Drlica, K.; Zhao, X. Nat. Microbiol. 2017, 2 (12), 1667-1675.

(73) Holmgren, A.; Lu, J. Biochem. Biophys. Res. Commun. 2010, 396 (1), 120-124.

(74) Olaitan, A. O.; Morand, S.; Rolain, J.-M. Front. Microbiol. 2014, 5.

(75) Yan, K.; Lok, C.-N.; Bierla, K.; Che, C.-M. Chem. Commun. 2010, 46 (41), 7691-7693.

(76) Epstein, T. D.; Wu, B.; Moulton, K. D.; Yan, M.; Dube, D. H. ACS Infect. Dis. 2019, 5 (10), 1682-1687.

(77) Fernandes, A. P.; Holmgren, A. Antioxid. Redox Signal. 2004, 6 (1), 63-74.

(78) Gusarov, I.; Nudler, E. Proc Natl Acad Sci U S A 2005, 102 (39), 13855-13860.

(79) Wu, B.; Yang, X.; Yan, M. J. Med. Chem. 2019, 62 (17), 7751-7768.

(80) Woodford, N.; Zhang, J.; Kaufmann, M. E.; Yarde, S.; Tomas, M. del M.; Faris, C.; Vardhan, M. S.; Dawson, S.; Cotterill, S. L.; Livermore, D. M. J. Antimicrob. Chemother. 2008, 62 (6), 1265-1268.

(81) Leifert, A.; Pan, Y.; Kinkeldey, A.; Schiefer, F.; Setzler, J.; Scheel, O.; Lichtenbeld, H.; Schmid, G.; Wenzel, W.; Jahnen-Dechent, W.; Simon, U. Proc. Natl. Acad. Sci. USA 2013, 110 (20), 8004-8009.

(82) Zhang, Q.; Yang, M.; Zhu, Y.; Mao, C. Curr. Med. Chem. 2018, 25 (12), 1379-1396.

(83) Galhardo, R. S.; Almeida, C. E.; Leitão, A. C.; Cabral-Neto, J. B. J. Bacteriol. 2000, 182 (7), $1964-1968$.

(84) Liu, Y.; Meyer-Zaika, W.; Franzka, S.; Schmid, G.; Tsoli, M.; Kuhn, H. Angew. Chem. Int. Ed. 2003, 42 (25), 2853-2857.

(85) Zheng, K.; Setyawati, M. I.; Leong, D. T.; Xie, J. Bioact. Mater. 2021, 6 (4), 941-950.

(86) Woehrle, G. H.; Warner, M. G.; Hutchison, J. E. J. Phys. Chem. B 2002, 106 (39), 9979-9981.

(87) CLSI. Performance standards for antimicrobial susceptibility testing. CLSI supplement M100; 2019. 